\title{
The era of bioengineering: how will this affect the next generation of cancer immunotherapy?
}

\author{
Michele Graciotti ${ }^{1}$, Cristiana Berti ${ }^{2}$, Harm-Anton Klok $^{2}$ and Lana Kandalaft ${ }^{1,3^{*}}$
}

\begin{abstract}
Background: Immunotherapy consists of activating the patient's immune system to fight cancer and has the great potential of preventing future relapses thanks to immunological memory. A great variety of strategies have emerged to harness the immune system against tumors, from the administration of immunomodulatory agents that activate immune cells, to therapeutic vaccines or infusion of previously activated cancer-specific T cells. However, despite great recent progress many difficulties still remain, which prevent the widespread use of immunotherapy. Some of these limitations include: systemic toxicity, weak immune cellular responses or persistence over time and most ultimately costly and time-consuming procedures.

Main body: Synthetic and natural biomaterials hold great potential to address these hurdles providing biocompatible systems capable of targeted local delivery, co-delivery, and controlled and/or sustained release. In this review we discuss some of the bioengineered solutions and approaches developed so far and how biomaterials can be further implemented to help and shape the future of cancer immunotherapy.
\end{abstract}

Conclusion: The bioengineering strategies here presented constitute a powerful toolkit to develop safe and successful novel cancer immunotherapies.

\section{Background}

Since its first application in 1890 by William Coley who treated cancer patients with a mixture of killed bacteria observing complete remission in $10 \%$ of cases [1], cancer immunotherapy has "travelled" a long way, culminating in 2010 with the first personalized immunotherapy approved by FDA against prostate cancer [2]. However, despite its surprising progress, many hurdles still persist that hamper success rates and wide applicability [3]. An anticancer immune response usually consists of an intricate network of events involving both innate and adaptive immune system first triggered by the uptake, processing and presentation of tumor antigens by antigen presenting cells (APCs), followed by $\mathrm{T}$ cell priming and activation and concluding with the infiltration of effector

\footnotetext{
${ }^{*}$ Correspondence: lana.kandalaft@chuv.ch

${ }^{1}$ Center of Experimental Therapeutics, Department of Oncology,

University Hospital of Lausanne, Lausanne, Switzerland

Full list of author information is available at the end of the article
}

$\mathrm{T}$ cells to the tumor site where they exert their cytotoxic activity potentially leading to tumor clearance (Fig. 1). Although this is a spontaneous and natural occurring process, tumors usually develop various mechanisms in order to escape this immune response (e.g. antigen loss, release of immunoinhibitory signals in the tumor microenvironment and others), usually referred to as immunoediting [4]. Several therapeutic approaches acting at different stages of the cancer immunity cascade have been developed over the years to overcome tumor immune escape. These can be classified in two: immunotherapies where cytokines or other immunomodulatory molecules are submitted to patients eliciting a cellular immune response in vivo, or immunotherapies where immune cells are generated, stimulated and expanded ex vivo and then injected into patients. In this review we will describe the current challenges that these approaches present and how biomaterials and bioengineering could help solving central issues to advance and improve cancer immunotherapy. 


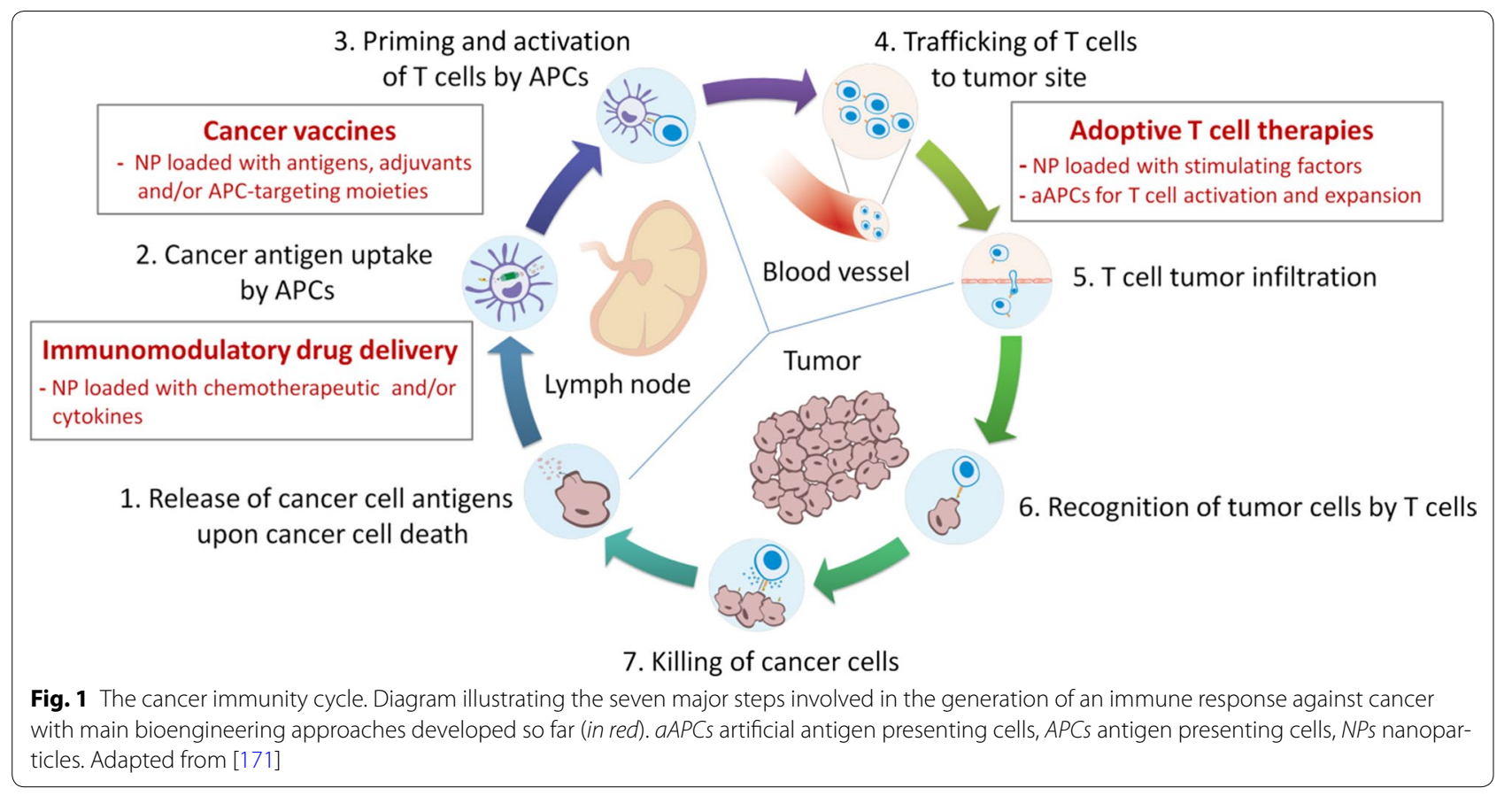

\section{Immunomodulatory drug delivery}

Chemotherapy is one of the most common therapies currently used for cancer treatment, however its application is often limited by large side effects linked to cytotoxic activity also on healthy tissues and cells, especially in patients already compromised by the disease. Although the use of cytotoxic drugs was traditionally thought to be immunosuppressive, this view is currently being changed by raising evidence [5]. One major factor to contribute in this sense is the so-called immunogenic cell death (ICD) which consists of the release of immunostimulatory molecules by cancer cells upon apoptotic cell death, leading to increased antigen uptake by dendritic cells (DCs) and immunization [6]. In recent years, to overcome side effects related to systemic administration, cancer drugs have been encapsulated in nanoparticles such as liposomes or poly(lactic-co-glycolic acid) (PLGA) nanoparticles (Fig. 2) and several are now FDA approved or being tested in clinical trials [7]. Nanoparticle encapsulation ensures tumor delivery thanks to both high vascular permeability and poor lymphatic drainage of the diseased tissue, leading to passive accumulation of nanoparticles at the tumor site (so-called EPR effect: enhanced permeability and retention effect) [8]. While the EPR effect has been shown to be effective in rodent models, translating this concept to the treatment of human cancers has proven more difficult [9]. Moreover, nanoparticles also provide increased drug stability due to shielding from the external environment, sustained release over time and increased local concentration. Interestingly, the impact of these approaches in the immunotherapy field is only starting to emerge very recently. A study by Zhao et al. showed for example that delivery of oxaliplatin by PLGA nanocarriers [10] (NP-OXA) induced a stronger immune response both in vitro (in co-culture assays of stimulated DCs and T-cells) and in immunocompetent mice, compared to oxaliplatin alone (OXA). In particular, NPOXA-treated mice showed a higher proportion of tumor infiltrated lymphocytes (TILs), higher IFN- $\gamma$ expression and increased tumor shrinkage compared to OXA treatment alone [10]. These results show that encapsulation improved the drug immunogenicity by increasing ICD, thus leading to a more pronounced immune response. On the contrary, no significant differences were recorded between mice treated with gemcitabine alone or encapsulated, confirming that not all chemotherapeutic drugs and formulations are able to induce ICD or possess immunostimulatory effects [11]. To that point, it will be important in the future to extend the test of chemotherapeutic nanomedicines also in immunocompetent mice instead of just the standard immunodeficient mice model [12] in order to investigate a possible role of the immune system in the response and fully reveal therapeutic potentials.

A similar strategy of nanoparticle encapsulation is also currently being pursued for the delivery of cytokines to boost and sustain the immune response against cancer cells in a more direct manner. Cytokines play a crucial role in stimulating and regulating the immune response against antigens, but their use in the clinic has been 


\begin{tabular}{|c|c|}
\hline Nanoparticle & Characteristics \\
\hline Liposomes & $\begin{array}{l}\text { Spontaneously-assembled bilayered membranes } \\
\text { containing an aqueous core. They can entrap both } \\
\text { hydrophobic and hydrophilic drugs, providing a } \\
\text { biocompatible and non-toxic drug delivery system. }\end{array}$ \\
\hline Synthetic polymers & $\begin{array}{l}\text { (e.g. PLGA, g-PGA) biocompatible and FDA-approved; } \\
\text { usually immunogenic, slow and sustained cargo } \\
\text { release. }\end{array}$ \\
\hline Natural polymers & $\begin{array}{l}\text { (e.g. albumin, HLA) biocompatible, biodegradable, non- } \\
\text { toxic, usually low immunogenic. Monomers can vary in } \\
\text { size which does not allow a strict control of the } \\
\text { features. Can be easily produced by cross-linking. }\end{array}$ \\
\hline Micelles & $\begin{array}{l}\text { nanosized aggregated formed by self-assembly of } \\
\text { amphiphilic, surfactant molecules in aqueous solution, } \\
\text { able to encapsulate water-unsoluble drugs. }\end{array}$ \\
\hline Dendrimers & $\begin{array}{l}\text { highly branched, symmetrical molecular that are } \\
\text { structurally perfect and monodisperse and which are } \\
\text { obtained by step-wise synthetic protocols via } \\
\text { convergent or divergent strategies. }\end{array}$ \\
\hline Gold nanoparticle & $\begin{array}{l}\text { Easily produced and highly stable; inert material; used } \\
\text { in thermal therapy, in vivo imaging, and in radio- } \\
\text { sensitization also in the clinic. }\end{array}$ \\
\hline $\begin{array}{l}\text { Carbon } \\
\text { nanoparticle }\end{array}$ & $\begin{array}{l}\text { Offers mechanical stiffness and chemical stability; } \\
\text { selectively enter the lymphatic vessels rather than } \\
\text { blood capillaries due to the molecular size and } \\
\text { permeability; particularly suitable for biomaging and } \\
\text { diagnostic applications as well as thermal therapy. }\end{array}$ \\
\hline Quantum dots & $\begin{array}{l}\text { Nanometer-sized crystals composed of } \\
\text { semiconductors; mainly used for diagnostic and } \\
\text { fluorescence imaging thanks to the ability of } \\
\text { multiplexing (distinct excitation and emission } \\
\text { wavelengths). }\end{array}$ \\
\hline Silica nanoparticle & $\begin{array}{l}\text { Non-toxic and biocompatible systems; easy to produce } \\
\text { and functionalize; are highly stable in a variety of } \\
\text { environments. }\end{array}$ \\
\hline $\begin{array}{l}\text { Ion oxide } \\
\text { nanoparticle }\end{array}$ & $\begin{array}{l}\text { Composed of magnetite or maghemite cores stabilized } \\
\text { with a hydrophilic surface coating; their magnetic } \\
\text { properties allow controlled delivery through external } \\
\text { magnetic fields. }\end{array}$ \\
\hline
\end{tabular}

Fig. 2 Nanoparticle classification and main characteristics. $\gamma$-PGA poly( $\gamma$-glutamic acid), HA hyaluronic acid, PLGA poly(lactic-co-glycolic acid) 
greatly limited due to harmful side effects linked with their pleiotropic nature and often dual role in simultaneously stimulating and suppressing the immune response at different levels [13]. As for chemotherapeutic drugs, nanoparticle encapsulation offers a potential solution also in this context by providing target delivery at the tumor site, therefore avoiding systemic toxicity. Recently, several groups have tested the delivery of IL-12 loaded on chitosan nanoparticles either as a recombinant protein $[14,15]$ or as encoding DNA for gene therapy [16], obtaining promising results. IL-12 is a powerful, proinflammatory cytokine that enhances $T_{H} 1$ cell differentiation, proliferation of activated $\mathrm{T}$ cells and natural killer (NK) cells and cell-mediated immunity [17]. Zaharoff et al. reported that IL-12/chitosan nanoparticles were superior to IL-12 alone in terms of overall survival and cytokine production in a mouse model of bladder cancer, further inducing $100 \%$ protection to tumor rechallenge in previously cured mice, lasting lymphocytic infiltration and a tumor-specific adaptive immune response [14, 15]. Significant results in terms of cytokine production and positive therapeutic outcome in mice have also been recorded with nanoparticle-mediated IL-12 gene therapy [16]. In addition, nanoparticle encapsulation has been reported for IL-2 [18-20], IL-15 [21], IL-10 siRNA [22], GM-CSF [23, 24], and the toll-like receptor (TLR) agonists CpG oligodeoxynucleotides (CpG-ODN) [25-27] and Poly I:C $[28,29]$, with positive outcomes in mouse models (Table 1). All these studies collectively confirmed the previous assumption that nanoparticle formulations are safer and induce better therapeutic effects than their free-soluble counterparts due to controlled local administration and higher concentration at the tumor site in virtue of the EPR effect. This innovative approach opens therefore a new scenario where immunomodulatory agents previously discontinued due to toxicity could be potentially reconsidered, improved by encapsulation and tested for future cancer immunotherapy. On the other hand, also treatments discarded due to low efficacy could be revisited and implemented in new biomaterials formulations [30]. Interestingly, a novel approach combining delivery of both cytotoxic drugs and cytokines through nanoparticles is also being pursued. The rationale here is of a "two-hit" strike to cancer cells: a "first-hit" due to the drug cytotoxic effect leading to cell apoptosis, activation of APCs and subsequent triggering of an immune response, and a "second-hit" which improves and sustains such immune response through the cytokine/TLR agonist action [10]. An example of this approach is the administration of lipid-coated cisplatin nanoparticles (LPC) followed by CpG-encapsulated liposomes 1 day after in a melanoma mouse model. Results showed that the combination treatment was far superior than both single mono-therapies in terms of controlling tumor growth, IFN- $\gamma$ production, favourable cytokine profile and immunological memory [31]. Another study used a sequential administration of hyaluronic acid-paclitaxel complex followed by two types of PLGA nanoparticles loaded respectively with CpG-ODN and IL-10 siRNA also showing effective and synergistic results [32]. Other studies in a mouse model successfully used instead simultaneous co-delivery of chemotherapeutic drugs and immunomodulatory agents loaded in the same nanoparticle (Table 1) [33, 34].

Concerning clinical work, several nanoparticles encapsulating chemotherapeutic drugs have been approved by FDA or are currently being tested in clinical trials for various types of malignancies; these include: liposomal doxorubicin [35-38], daunorubicin [39-43], irinotecan [44], vincristine [45-48] and albumin-bound paclitaxel (nab-paclitaxel) [49-52]. Despite this, clinical studies in combination with immunotherapy regimens are only slowly starting to emerge. One recent Phase I study investigated the combination of $n a b$-paclitaxel with immunotherapy (co-administration of soluble IL-2 and IFN- $\alpha$ ) in metastatic melanoma, but the study failed to identify the maximum tolerated dose due to recorded toxicity at the lowest concentration tested and also the limited number of patients enrolled (10) [53]. On the other hand, a Phase Ib study in metastatic triple-negative breast cancer patients confirmed the safety and the therapeutic benefit of a combination of a checkpoint inhibitor (anti-PD-L1: atezolizumab) with $n a b$-paclitaxel, setting the basis for an ongoing Phase III clinical trial [54]. Finally, another Phase I study in recurrent ovarian cancer provided evidence for safety and biological activity of pegylated liposomal doxorubicin in combination with interleukin-18 [55]; similar positive outcomes were also reported for a combination of liposomal doxorubicin, anti-IL6-receptor antibody and IFN- $\alpha[56]$.

In light of these studies, it is clear that further work will be needed in the future to establish what the best encapsulation and administration strategies are (e.g. coencapsulation and co-delivery versus sequential administration) as well as to identify the best drug combinations. To help the clinical translation the different formulations should also be tested in more sophisticated systems such as immunocompetent and/or humanized mouse models [57]. Finally, nanotherapies previously tested in humans (i.e. nab-paclitaxel) should be further investigated in combination with immunostimulatory agents (e.g. interleukins, checkpoint inhibitors, etc.) with and/or without encapsulation to potentially improve therapeutic outcomes [58]. 
Table 1 List of recent studies investigating nanoparticle-mediated delivery of immunomodulatory agents

\begin{tabular}{|c|c|c|c|c|}
\hline Carrier & Agent & Model system & Outcome $^{a}$ & References \\
\hline mPEG-PLGA & Oxaliplatin & Pan02 pancreatic cancer mouse model & $\begin{array}{l}\text { Increased TIL levels, increased IFN- } \gamma \\
\text { production }\end{array}$ & [10] \\
\hline Chitosan & $\mathbb{I L}-12$ & MB49 bladder tumor mouse model & $\begin{array}{l}\text { Induced antitumoral activity and } T_{H} 1 \\
\text { cytokine expression }\end{array}$ & [14] \\
\hline Chitosan & $\mathrm{IL}-12$ & $\begin{array}{l}\text { MB49 and MBT-2 bladder tumor mouse } \\
\text { models }\end{array}$ & $\begin{array}{l}100 \% \text { protection to tumor rechallenge in } \\
\text { previously cured mice }\end{array}$ & [15] \\
\hline Liposome & Cisplatin CpG & B16-F10 melanoma mouse model & $\begin{array}{l}\text { Tumor clearance, long-term protection, } \\
\mathrm{T}_{\text {reg }} \text { downregulation }\end{array}$ & {$[31]$} \\
\hline Nanodiamond & CpG & $\begin{array}{l}\text { B16-F0 melanoma and } 4 \mathrm{~T} 1 \text { breast cancer } \\
\text { mouse models }\end{array}$ & IL-12 production and tumor shrinkage & {$[25]$} \\
\hline PEl & IL-2 plasmid & B16-F1 melanoma mouse model & $\begin{array}{l}\text { Reduced tumor growth, prolonged sur- } \\
\text { vival, increased TIL tumor infiltration }\end{array}$ & {$[18]$} \\
\hline Chitosan & IL-2 plasmid & $\begin{array}{l}\text { BALB/C mouse inoculated with WEHI-164 } \\
\text { in vitro transfected cells }\end{array}$ & Tumor mass volume decrease & [162] \\
\hline Hydroxyethyl starch & $\mathrm{IL}-2$ & $\begin{array}{l}\text { C57BL/6 mouse model; Rag2 } 2^{-/-} \mathrm{YC}^{-/-} \text {mice } \\
\text { reconstituted with human } \mathrm{CD}^{+} \mathrm{T} \text { cells }\end{array}$ & In vivo T cell specific uptake & {$[20]$} \\
\hline Nanolipogel & IL-2 and TGF- $\beta$ inhibitor & B16-F10 melanoma mouse model & $\begin{array}{l}\text { Increased survival } \\
\text { Increased CD8 }{ }^{+} T \text { cells tumor infiltration }\end{array}$ & [19] \\
\hline Polylactic acid & $\begin{array}{l}\text { IL-12, IL-18, TNF-a alone } \\
\text { or in combinations }\end{array}$ & $4 \mathrm{~T} 1$ breast cancer mouse models & $\begin{array}{l}\text { IL-12 and TNF-a combination was the } \\
\text { best condition for controlling tumor } \\
\text { growth }\end{array}$ & [163] \\
\hline PLGA-PEI & CpG, IL-10 siRNA & A20 B-cell lymphoma mouse model & $\begin{array}{l}\text { Improved } T_{H} 1 / T_{H} 2 \text { cytokine expression } \\
\text { ratio, Increased survival }\end{array}$ & [22] \\
\hline $\begin{array}{l}\text { HA } \\
\text { PLGA } \\
\text { PLGA }\end{array}$ & $\begin{array}{l}\text { Paclitaxel } \\
\text { CpG } \\
\text { IL-10 siRNA }\end{array}$ & B16-F10 melanoma mouse model & $\begin{array}{l}\text { Tumor growth inhibition } \\
\text { High } T_{H} 1 / T_{H^{2}} \text { cytokine expression ratio }\end{array}$ & [32] \\
\hline PPS & CpG & E.G7-OVA and B16F10 mouse model & $\begin{array}{c}\text { Enhanced } \mathrm{T}_{H} 1 \text { cytokine secretion and } \\
\text { protection to tumor rechallenge }\end{array}$ & [26] \\
\hline silica & GM-CSF & In vitro & Increased macrophage proliferation & [24] \\
\hline Zinc oxide & Poly $1: C$ & B16-F10 mouse melanoma model & suppressed tumor cell growth & [28] \\
\hline PS & Poly $1: C$ & C57BL/6 mouse model & $\begin{array}{l}\text { High IL6 production; tnfa, il15, il18, mip3a, } \\
\text { and ip } 10 \text { mRNA upregulation }\end{array}$ & [164] \\
\hline PLGA & Paclitaxel LPS & B16-F10 mouse melanoma model & Increased TIL levels and tumor regression & [33] \\
\hline Pyridyl disulfide & Paclitaxel or CpG & B16-F10 mouse melanoma model & $\begin{array}{l}\text { Slowed tumor growth, increased } \mathrm{CD}^{+} \text {/ } \\
\mathrm{CD} 4^{+} \mathrm{T} \text { cell ratio }\end{array}$ & {$[27]$} \\
\hline Albumin & Paclitaxel & Phase I studies & $\begin{array}{l}\text { Combination with IL-2, IFN-a, cisplatin } \\
\text { and temozolomide was too toxic; } \\
\text { combination with atezolizumab was } \\
\text { well tolerated }\end{array}$ & {$[53,54]$} \\
\hline Liposome & DOX & Phase I study & $\begin{array}{l}\text { Combination with IL-18 is safe and bio- } \\
\text { logically active }\end{array}$ & {$[55]$} \\
\hline PEG-liposome & DOX & Phase I study & $\begin{array}{l}\text { Functional IL-6R blocking with tocili- } \\
\text { zumab is feasible and safe in combina- } \\
\text { tion with PEG-liposomal DOX }\end{array}$ & {$[56]$} \\
\hline
\end{tabular}

DOX doxorubicin, HA hyaluronic acid, LPS bacterial lipopolysaccharide, PEG polyethylene glycol, PEI polyethylenimine, PLGA poly(lactic-co-glycolic acid), PPS poly(propylene sulphide), PS polysaccharide, TIL tumor infiltrating lymphocytes

a Compared to free soluble agent, when applicable

\section{Adoptive T cell therapy}

Adoptive $\mathrm{T}$ cell therapy (ACT) consists of the isolation of autologous tumor specific $\mathrm{T}$ cells from the patient's peripheral blood or tumor biopsies, followed by ex vivo expansion and patient re-infusion to elicit an anti-cancer immune response [59]. Alternatively (especially for those type of cancers where cancer-specific $\mathrm{T}$ cells are less spontaneously occurring), $\mathrm{T}$ cells can be expanded from patient-genetically modified $\mathrm{T}$ cells expressing a tumorspecific T Cell Receptor (TCR) or a chimeric TCR composed of a synthetic antigen-binding Ig domain fused with TCR signalling components, called CAR receptor [60]. Despite promising results yielded in clinical trials for melanoma [61-63] and other cancer types [64-66], 
ACT still suffers from important drawbacks and challenges that limit its widespread use. Some of the major limitations include: (1) the time-consuming and costly procedure of ex vivo cell expansion which requires 5-6 weeks and specific equipment (e.g. bioreactors), (2) $\mathrm{T}$ cell persistence and functionality after infusion which usually necessitate administration of survival factors, and (3) systemic toxicity. Bioengineering approaches have recently tried to solve those issues by employing biomaterials in different ways. One successful strategy developed by Irvine and colleagues (so far in mouse models) is to conjugate nanoparticles loaded either with stimulating factors (IL-15 and IL-21) [67] or an immunosuppressionblocking drug (NSC-87877) [68] directly on the surface of expanded $\mathrm{T}$ cells, prior to infusion. Interestingly, this strategy enabled the local delivery of immunomodulatory agents at high concentration that sustained $\mathrm{T}$ cell proliferation and effector function with greatly increased therapeutic advantages and minimized toxic effects compared to systemic infusion $[67,68]$. In a follow-up study, nanoparticles were decorated with $\mathrm{T}$ cell targeting antibodies and used to stimulate ACT cells in vivo instead of ex vivo prior to infusion [69]. This approach has the advantage of enabling multiple rounds of stimulation by repeated nanoparticle injections rather than a single stimulation step ex vivo. In particular, $\mathrm{T}$ cell targeting was achieved using either an ACT-T cell specific surface antigen (Thy1.1) to restrict targeting only to ACT cells, or IL-2 which would target less specifically the whole $\mathrm{T}$ cell compartment but with the advantage of providing also a stimulating signal. Results showed successful targeting efficiency of ACT cells with low binding to endogenous $\mathrm{T}$ cells in both cases; however IL-2-loaded nanoparticles were also able to induce repeated waves of ACT T cell expansion in tumor-bearing mice upon multiple injections, thanks to IL-2 signalling. Based on this proof-ofconcept, current work is focusing now on loading drugs and immunomodulatory molecules on these T-cell targeting nanoparticles to further improve ACT therapeutic efficacy [69].

Concerning CAR $\mathrm{T}$ cells, a very recent breakthrough study explored the possibility to programme $\mathrm{T}$ cell in situ with the injection of DNA-carrying nanoparticles [70]. In particular, these nanoparticles were coated with antiCD3 antibodies to target the $\mathrm{T}$ cell compartment and loaded with DNA encoding for a leukaemia-specific CAR T cell receptor. Tests in an immunocompetent leukaemia murine model showed correct $\mathrm{T}$ cell transduction and proliferation, leading to disease regression with an efficacy comparable to conventional adoptive CAR $\mathrm{T}$ cell therapy as well as reporting general safety without any systemic toxicity [70]. Such an approach is very promising since it circumvents the need to isolate and manipulate $\mathrm{T}$ cells ex vivo, an aspect linked with the major hurdles of current ACTs (see above) and it should be therefore further investigated in the future for other cancer types as well as considered for clinic translation. Another explored route to improve current ACTs is the employment of artificial antigen presenting cells (aAPCs) to stimulate $\mathrm{T}$ cell expansion. To provide appropriate signalling, aAPCs must present on their surface a peptideMHC complex that binds to the TCR (signal 1) and a CD28 antibody to provide co-stimulatory signalling (signal 2); in addition they could also provide adjuvants such as IL-2, IL-15 or IL-21 to further sustain T cell expansion (signal 3) [71]. aAPCs offer the advantage of avoiding the need to generate patient-specific DCs to stimulate tumor-specific $\mathrm{T}$ cells either ex vivo or in vivo as well as providing a versatile and cost-effective platform for $\mathrm{T}$ cell stimulation and expansion. On the other hand, a major disadvantage is the surface rigidity that fails to recapitulate the dynamic changes of the APC surface upon T-cell interaction. Important breakthroughs have been made recently in this field, thanks to the employment of biomaterials, substantially contributing to improve aAPC efficacy. Initial studies demonstrated that polymer-based nanoparticles were much less efficient than microparticles in inducing in vitro $\mathrm{T}$ cell functional responses (with notably no proliferation) suggesting that micron-sized beads, which are close in size to $\mathrm{T}$ cells, provide optimal T-cell stimulation [72]. However, Perica et al. recently reported a nano-sized aAPC platform based on either iron-dextran paramagnetic nanoparticles or quantum dot nanocrystals both able to induce antigen specific- $T$ cell proliferation and tumor shrinkage in a melanoma mouse model [73]. This discovery constitutes a critical improvement for aAPCs in vivo applications since, contrary to micro-sized particles, nano-sized ones are able to passively drain to lymph nodes [74] where they could gain access to a large pool of $\mathrm{T}$ cells to prime, making them more suitable and efficient for in vivo administration. The same group has also recently developed aAPC magnetic nanoparticles conjugated to CD28-antibody and MHC-Itumor antigen complexes as a strategy to isolate tumorspecific $\mathrm{T}$ cells from peripheral blood using magnetic columns, followed by ex vivo expansion [75]. The enrichment step was used to remove unspecific $\mathrm{T}$ cells that would compete with tumor-specific $\mathrm{T}$ cells for growth factors and decisively improved the antigen-specific cell fold expansion both in vitro and in vivo after transfer. Other important improvements came from using ellipsoidal micro-particles instead of spherical ones in order to decrease the surface curvature and therefore increase the area available for T-cell contact [76] highlighting the importance of not only the stimulating signals, but also the geometry and design of aAPCs to provide a successful 
stimulation. In light of this, it will be important in the future to also explore alternative geometries to mimic for example membrane protrusions or lamellipodia that are involved in T cell-APC interactions [77], in an attempt that will stimulate both the cancer immunotherapy and the bioengineering fields providing future synthetic challenges [78]. Finally, while up to now aAPCs have been prepared by randomly distributing ligands on their surface, recent studies suggest that the juxtaposition and the relative positions of signal 1 and 2, as well as their surface density $[79,80]$, are also important to efficiently stimulate $\mathrm{T}$ cells [78]. For example, using planar arrays it was shown that the presence of anti-CD28 at the periphery of the $\mathrm{T}$ cell contact site increased IL-2 secretion by CD4 T cells compared with having these signals combined in the center of the synapse [81]. The need to precisely control the pattern and distribution of ligands constitutes therefore another challenge for future bioengineering synthetic approaches.

\section{Cancer vaccines}

Therapeutic cancer vaccines consist of using cancer antigens to pulse dendritic cells either in vivo or ex vivo followed by administration to patients to induce a cancer-specific immune response. These vaccines are therapeutic rather than preventive, since they are designed to treat a disease, which is already in course. The first attempts in this sense were injections of autologous tumor cells or tumor specific proteins administered alone or with an adjuvant [82-84], while more recently an alternative strategy has been developed by stimulating directly dendritic cells ex vivo with tumor associated or specific antigens (TAAs, TSAs) or whole tumor lysate (WTL) which are then re-infused into patients; this with the advantage of manipulating DCs during pulsing and activation to further improve their immunogenicity [85]. To this aim, dendritic cells can be obtained ex vivo by isolating monocyte precursors from peripheral blood followed by incubation with specific growth factors and cytokines such as GM-CSF, IL-4, IL-3, Flt3 ligand and c-Kit [86]. A great limitation of using TAAs is that the antigen(s) used has to be first identified and characterized which is not always possible for all types of cancers and it often requires extensive procedures. Moreover, there is also the possibility of immune escape by antigen loss from cancer cells [87]. Alternatively, DCs have also been pulsed with autologous WTL obtained from patient's cancer cells by irradiation or cycles of freezing and thawing with the advantage of using a much larger pool of potential antigens and also avoiding the need for antigen identification [88-91]. Our group recently reported that $\mathrm{HOCl}$ oxidation of WTL prior to DCs ex vivo pulsing and maturation increased the uptake and presentation as well as improving the therapeutic outcome in an ovarian Phase I clinical trial [92, 93]. Another approach to increase immunogenicity of the lysate is to use heat, allowing increased production of heat shock proteins that further activate the immune response. This approach was tested in a pancreatic cancer mouse model with promising results [94]. Nonetheless, generating and activating DCs ex vivo is a time-consuming and costly procedure that can be potentially overcome using biomaterial vectors to deliver antigen(s) in situ. In recent years bio- and synthetic materials such as hydrogels, liposomes, matrices and nanogels which have the common feature of being biocompatible and non-toxic have been tested for the delivery of tumor antigen(s) in micro and nanoparticles in a great variety of combinations of different building blocks, antigens, adjuvants and targeting molecules (Table 2) [95]. Among these, due to their high biocompatibility and easy approval, liposomes have been largely explored and have also been tested in the clinic. Unfortunately, while certain formulations have shown discrete success in Phase I [96-100] and II trials $[101,102]$ showing good tolerance and survival improvement, Phase III trials have been less successful reporting limited benefits (BLP25 [103]) or failed to meet study endpoints (Allovectin-7 [104], product discontinued; Table 2). A major drawback of liposomes is their very short half life in the body and rapid clearance that limits the time frame in which they are active, a feature that could well be at the base of their reported failures [105]. A possible solution to this problem could be potentially offered by the implementation of Poly(lactic-co-glycolic acid) or PLGA in nanovaccine formulations. PLGA offers the advantage of being itself an immunostimulating agent, contributing therefore to the overall immune stimulation process rather that just acting as an inert carrier as well as being characterized by longer persistence in the human body and slow cargo release [105]. Several types of antigens such as proteins (e.g. ovalbumin (OVA) $[106,107]$, peptides (e.g. Hgp $100_{25-33}$; TRP2 $2_{180-188}$ ) [108, 109] and WTLs [110-113] have been encapsulated in PLGA nanoparticles and tested in in vitro systems and/ or in mouse models showing positive outcomes in terms of efficient antigen delivery and elicited tumor-specific $T$ cell responses. However none of these different formulations have been tested in humans yet. Another biopolymer tested in the clinic for cancer vaccine delivery is cholesteryl pullulan. Phase I trials in esophageal [114] or HER2-expressing $[115,116]$ cancer patients were carried out delivering well established cancer antigens (NY-ESO-1 protein and HER2 fragment, respectively) reporting good tolerance and the occurrence of antigen specific immune responses, while no Phase II or III trials appeared so far in the literature to our knowledge. 
Table 2 List of recent studies investigating nanoparticle-mediated delivery of tumor antigen(s) either alone or in combination with adjuvant(s)/DC-targeting moieties for cancer therapeutic vaccination

\begin{tabular}{|c|c|c|c|c|}
\hline Carrier & Loaded with & Study type & Outcome $^{a}$ & References \\
\hline Liposome & Hsp70 peptide complex & $\begin{array}{l}\text { Breast cancer mouse } \\
\text { model }\end{array}$ & Enhanced immune response & [165] \\
\hline Liposome & $\begin{array}{l}\text { MUC1 peptide, TLR4 } \\
\text { ligand }\end{array}$ & Phase I-II-III studies & $\begin{array}{l}\text { Phase I studies: vaccine was well tolerated; phase II study in } \\
\text { NSCLC: survival improvement; Phase III study in NSCLC: only } \\
\text { improvement observed was in concurrent chemoradiother- } \\
\text { apy with a } 10.2 \text { month improvement in median survival }\end{array}$ & {$[96,97,101,103]$} \\
\hline Liposome & $\begin{array}{l}\text { HLA-B7 and } \\
\text { B2-microglobulin DNA }\end{array}$ & Phase II-III studies & $\begin{array}{l}\text { Phase II study in metastatic melanoma had a positive outcome, } \\
\text { but phase III study failed and product is currently discontin- } \\
\text { ued }\end{array}$ & {$[102,104]$} \\
\hline Liposome & $\begin{array}{l}\text { NY-ESO-1, MAGE-A3, } \\
\text { tyrosinase and TPTE } \\
\text { RNA }\end{array}$ & Phase I study & $\begin{array}{l}\text { Positive outcome in all } 3 \text { patients tested. Recruitment of more } \\
\text { patients is currently undergoing }\end{array}$ & [98] \\
\hline Liposome & Mix of different peptides & Phase I study & $\begin{array}{l}\text { Phase I trial positive outcome, with induced de novo and } \\
\text { specific T cell response }\end{array}$ & {$[99,100]$} \\
\hline Liposome & SOCS1, A20 siRNA & Mouse lymphoma model & $\begin{array}{l}\text { Drastic enhancement in cytokine production resulting in } \\
\text { significant tumor suppression }\end{array}$ & {$[166]$} \\
\hline Liposome & E7 HPV & TC-1 lung mouse model & Induced specific $C D 8^{+} \mathrm{T}$ cell response and $\mathrm{T}_{\text {reg }}$ inhibition & {$[167]$} \\
\hline Liposome & OVA, TLR3/9 ligands & C57BL/6 mouse model & Increased $\mathrm{CD} 8^{+} \mathrm{T}$ cell response & [123] \\
\hline $\begin{array}{l}\text { Y-PGA/Pol- } \\
\text { ylysine }\end{array}$ & Empty or ovalbumin & C57BL/6 mouse model & $\begin{array}{l}\text { Comparative study: PGA has intrinsic immunogenic properties } \\
\text { and induced a stronger immune response than polylysine } \\
\text { when both loaded with ovalbumin }\end{array}$ & {$[160]$} \\
\hline$\gamma-P G A$ & Ovalbumin & C57BL/6 mouse model & Y-PGA immunogenic properties are TLR4 signalling-dependent & [168] \\
\hline $\begin{array}{l}\text { Cationic } \\
\text { polymers } \\
\text { (PE/C32) }\end{array}$ & $\begin{array}{l}\text { CD40 ligand DNA, } \\
\text { CpG + poly }(1: C)\end{array}$ & $\begin{array}{l}\text { B16-F10 melanoma } \\
\text { mouse model }\end{array}$ & $\begin{array}{l}\text { Comparative study: C } 32 \text { polimer was superior to PE. TLR } \\
\text { ligands had a synergistic effect in triggering immune } \\
\text { response }\end{array}$ & [124] \\
\hline PLGA & WTL & In vitro & $\begin{array}{l}\text { Co-culture of patient TILs with patient DCs pulsed with } \\
\text { autologous WTL-NPs resulted in higher IFN- } y \text { and lower IL-10 } \\
\text { production compared to soluble WTL }\end{array}$ & {$[110,111]$} \\
\hline PLGA & WTL, CpG, polyl:C & TRAMP mouse model & Induced CTL response and tumor shrinkage & [112] \\
\hline PLGA & WTL & In vitro & Increased T cell proliferation & [113] \\
\hline PLGA & $\begin{array}{l}\text { Ovalbumin TLR3/7 } \\
\text { ligands; CD40, CD11c, } \\
\text { or DEC-205 ab }\end{array}$ & C57BL/6 mouse model & $\begin{array}{l}\text { NP coating with targeting molecules (CD40, CD 1 1c or DEC-205 } \\
\text { antibodies) induced a stronger immune response }\end{array}$ & {$[106]$} \\
\hline PLGA & Ovalbumin, mannose & C57BL/6 mouse model & $\begin{array}{l}\text { Decoration of ovalbumin-NPs with mannose moieties } \\
\text { increased the efficiency of ovalbumin-specific CD4 }{ }^{+} \text {and } \\
\text { CD8 } 8^{+} T \text { cell responses }\end{array}$ & {$[107]$} \\
\hline PLGA & TRP2 $2_{180-188 ;}$ TLR-4 ligand & $\begin{array}{l}\text { B16-F10 melanoma } \\
\text { mouse model }\end{array}$ & $\begin{array}{l}\text { Immune stimulation in the tumor microenvironment, induc- } \\
\text { tion of antigen-specific } C D 8^{+} \text {response }\end{array}$ & {$[108]$} \\
\hline PLGA & $\mathrm{Hgp} 100_{25-33} \operatorname{TRP}_{180-188}$ & C57BL/6 mouse model & Increased antigen-specific T cell response & [109] \\
\hline $\begin{array}{l}\text { Cholesteryl } \\
\text { pullulan }\end{array}$ & $\begin{array}{l}\text { HER2 fragment; NY- } \\
\text { ESO-1 protein }\end{array}$ & Phase I studies & $\begin{array}{l}\text { Vaccine was well tolerated and induced antigen-specific } \\
\text { immune responses }\end{array}$ & [114-116] \\
\hline Chitosan & Ovalbumin, alginate & In vitro & $\begin{array}{l}\text { Sugar-coated NP induced higher IFN-y production in co- } \\
\text { culture assays }\end{array}$ & [169] \\
\hline Chitosan & WTL, mannose & $\begin{array}{l}\text { B16 melanoma mouse } \\
\text { model }\end{array}$ & Increased tumor growth inhibition & {$[117]$} \\
\hline $\begin{array}{l}\text { BSA/pyri- } \\
\text { dine }\end{array}$ & Ovalbumin & In vitro & This type of nanogel had intrinsic adjuvant properties & {$[170]$} \\
\hline Nanogel & Ovalbumin, galactose & B16-OVA mouse model & $\begin{array}{l}\text { (pH-sensitive system) cytosolic antigen release; ROS produc- } \\
\text { tion and increased MHC-I antigen presentation }\end{array}$ & [133] \\
\hline
\end{tabular}

Y-PGA poly(y-glutamic acid), BSA bovine serum albumin, NP nanoparticle, NSCLC non-small-cell carcinoma, $P L G A$ poly(lactic-co-glycolic acid), TLR toll-like receptor, TRAMP transgenic adenocarcinoma of the mouse prostate, WTL whole tumor lysate

a Compared to free soluble agent, when applicable 
Among other materials, chitosan also showed promising results for future translational applications. Chitosan is a cationic polysaccharide able to elicit an adjuvant innate immune response, like PLGA, further triggering DCs maturation. A recent study showed for example that subcutaneous injections of these NPs loaded with WTL in mice induced a specific cytotoxic T cell (CTL) response and reduced tumor size compared to control groups [117]. In an attempt to further improve particle uptake, DC-targeting and DC-maturation, several studies have used nano- or microparticles coated with DC-targeting ligands such as anti-CD40 [106, 118], anti-DEC-205 [106, $119,120]$, anti-SIGN [121, 122], carbohydrates [107, 122] and/or TLR agonists $[112,123,124]$ (Table 2). Collectively, results from all these studies confirmed the previous assumption that particle coating (or encapsulation in the case of TLR agonists) indeed improves DC maturation, antigen internalization and presentation, inducing a stronger immune response compared to non-targeted nanovaccines or free antigen(s) in mouse model systems. Few comparative studies were also able to identify better formulations over others (e.g. uptake of SIGN-antibody coated-nanoparticles was more efficient that carbohydrates-coated ones [122]; or, in another study, coating with CD-40 ligand was superior to DEC-205 or CD11c in terms of uptake [106]), even though a systematic classification and comparison is still lacking.

Another direction in which nanovaccine research has recently focused on is the development of $\mathrm{pH}$-sensitive nanoparticles. These nanoparticles, once internalized, are able to disrupt endosomes leading to antigen(s) release in the cytosol, a process known to promote cross presentation by DCs and enhance CTL over humoral response [125]. This approach has been successfully attempted with different biomaterials including liposomes [126128], hydrogels [129], micelles [130, 131] and synthetic polymers [132]. Overall, all these studies used nanoassisted delivery of OVA in mice as a model system and showed positive results including increased MHC-I antigen presentation and induction of OVA-specific $\mathrm{CD} 8^{+}$ $\mathrm{T}$ cell response. Furthermore, a recent study using a pHsensitive galactosyl dextran-retinal (GDR) nanogel for OVA encapsulation was able to show that the lysosome rupture triggered by nanoparticles could directly induce reactive oxygen species (ROS) production in DCs, augmenting proteasome activity and downstream MHC I antigen presentation [133]. These interesting results suggest therefore that $\mathrm{pH}$-sensitive nanocarriers constitute a very promising scaffold for future translational work.

In conclusion, a great variety of scaffolds, materials and antigens have been tested for cancer vaccine delivery alone or in combination with specific surface receptors, and adjuvants that can improve DC-targeting and maturation. Despite these efforts achieved important results, further comparative studies are needed in order to understand which are the most promising and suitable biomaterials and to identify the best combinations of antigen(s), adjuvants and targeting molecules to obtain the best immune response. Enhancement of cross presentation by cytosol localization of the antigen(s) plays also a significant role in terms of $\mathrm{CD}^{+} \mathrm{T}$ cell polarization and should be studied and exploited in-depth in the future. Finally, tests in more complex systems that better represent human settings (e.g. humanized mouse models) [57] and for the delivery of epitopes more clinically relevant (e.g. other than OVA) or more immunogenic (e.g. oxidized WTL $[92,93]$ or heated lysate [94]) will help in translating these strategies into the clinic as well as potentially achieving better therapeutic outcomes.

\section{Circulating tumor cells isolation and detection}

Circulating tumor cells (CTCs) are cancer cells that shed from the tumor primary site and after entering the bloodstream extravasate and arrest at a second distal site to initiate cancer metastasis [134]. Despite their first report dates back to 1869 [135], a great amount of interest towards CTCs and their use as predictive biomarkers for cancer metastasis has only emerged in the last two decades. This is mainly due to the technical challenges linked with detecting and isolating very rare cells (usually one in $10^{6}-10^{9}$ hematologic cells [136]) which are also often highly heterogenic [137-139]. Several bioengineering solutions have been recently developed addressing these issues. One common strategy employs magnetic nanoparticle coated with specific ligands targeting CTCs (e.g. anti-EpCAM) that enables CTC separation and enrichment from blood samples by simply applying a magnetic field [136]. Other isolation techniques rely on $\mathrm{Au}$ nanoparticles, quantum dots, graphene or dendrimers coated with different CTC-targeting moieties such as lectins, tumor antigens or aptamers and have already been extensively reviewed elsewhere [140-142]. Despite great advances in biomaterial formulations for the detection and isolation of CTCs, their therapeutic implications have been largely unexplored yet, especially in the immunotherapy field. CTCs can be in fact isolated with a "simple" blood test (often referred to as liquid biopsy), contrary to solid tumors which require invasive surgery, and constitute a precious tool to assess genotypic and phenotypic features at a personalized level [143]. For example, CTCs genotyping and phenotyping could be potentially used to inform cancer vaccination strategies permitting the identification in real time of present antigens or, on the opposite, of antigen-loss due to selective pressure. On the other hand, isolated CTCs could constitute also a potential source of antigens to pulse autologous dendritic cells 
for personalized cancer vaccine formulations. Analogous strategies have been recently applied to instruct chemotherapeutic regimens such as HER2-receptor antagonists in breast cancer patients. Surprisingly, in several cases HER2 was detected in CTCs in metastatic patients that were previously negative at original diagnosis at the primary tumor site [144-146] and in one particular study three over four of these patients treated with anti-HER2 therapy (trastuzumab) showed evidence of complete or partial response [145]. These examples, besides demonstrating the heterogeneity and the dynamic nature of cancer, illustrate also the critical role that CTCs could play in guiding therapeutic efforts [147]. Thus, we envisage that in the future new studies will appear linking CTCs analysis and detection with immunotherapy. However, the success of these future approaches will rely in the high yield isolation of CTCs in a viable form. To this aim, several proof-of-concept studies showed the possibility to isolate CTCs from leukapheresis products, in order to screen blood volumes much larger ( 10 L) than the commonly used for CTCs analysis (5-10 mL) [148-150]. Alternatively, other groups are developing implantable scaffolds that are able to capture and trap CTCs which could be subsequently recovered and analyzed [151, 152]. In addition to this, the material could also be seeded with cells, or adjuvants to modulate the immune environment within the scaffold [152]. Ongoing work is focusing in further developing these proof-of-concept studies towards translational applications. It should also be noted that developments in CTCs sequestering and elimination will be immensely powerful in fighting cancer, considering that $90 \%$ of cancer mortality is caused by metastasis [153]; hence efforts in this direction could be potentially extremely rewarding.

\section{Route of administration}

One of the crucial aspects for a successful nanotherapy is the route of administration which should ensure both targeted delivery of the regimen at its active site (this being for example the tumor site or the lymph nodes) combined with as few as possible collateral effects and invasiveness. Regarding those formulations that target the tumor site, several studies applied intratumoral or peritumoral injection of nanoparticles loaded with immunostimulatory molecules (such as: IL-12 [154], IL-15 superagonist [155], IL2 and TGF- $\beta$ [19] among others) with positive outcomes, reporting the initiation of an immune response in tumor-bearing mice. Interestingly, one particular study demonstrated how intratumoral injection of liposomes carring anti-CD137 and IL-2 enabled an otherwise lethal treatment (compared to soluble anti-CD137 and IL-2) [156]. Although intratumoral injection ensures high local drug concentration and targeted delivery, a lot of studies apply more straightforward intravenous or subcutaneous injections and exploit instead the above mentioned EPR effect to passively accumulate the cargo at the tumor site. However, raising evidence suggests that the EPR effect works in rodents but not in humans (probably due to the large differences in tumor-to-body weight ratio and differences in the tumor microenvironment, between murine models and human cancers) [9], a fact that should be taken into careful consideration for clinical translation. In particular, this issue could potentially be solved by coating the surface of nanocarriers with ligands targeting receptors overexpressed by cancer cells (e.g. transferrin, folate, epidermal growth factor or glycoproteins receptors [157]) allowing therefore a more focused and active targeting.

Regarding formulations that target instead lymph nodes (e.g. cancer vaccines), nanocarriers can be administered either parentally (intramuscularly or subcutaneously, as in the majority of the studies), or intranodally. In the former case, the size of the nanoparticle is crucial in determining the mechanism of trafficking to the lymph nodes. In fact, while smaller particles $(<200 \mathrm{~nm})$ are able to passively drain through lymphatic system to finally reach the lymph nodes, larger particles cannot and have to be first engulfed by peripheral DCs which then migrate from the injection site to the lymph nodes [74]. On the other hand, the intranodal injection, although more technically challenging and invasive, ensures direct delivery and accumulation at the lymph node enabling the use of also microparticles which, contrary to nanoparticles, are able to persist longer at the lymph node releasing their cargo in a more prolonged and sustained fashion [158].

Finally, in an effort to balance improved targeted delivery versus limited invasiveness, a recent study pioneered the use of microneedle patches (MNs) to deliver antibodies against the checkpoint inhibitors PD1 and CTL4 in a melanoma mouse model. Results showed that MNs can painlessly pierce the mouse skin and efficiently deliver their cargo to regional lymph and capillary vessels ensuring disease control in $70 \%$ of mice over 2 months (end time point) [159]. This promising proof-of-concept study shows therefore that MNs could efficiently combine target delivery with easy and non-invasive administration, holding great potential for delivery of also other immunotherapeutic regimens in the future.

\section{Conclusion and future perspectives}

As highlighted by the sheer amount of studies reviewed here, nanoparticle delivery systems are a very versatile platform to address crucial limitations of current cancer immunotherapy, both in vivo and ex vivo. In particular, nanotechnology and bioengineering approaches have greatly enhanced the efficacy of immunotherapies 
by ensuring targeted delivery, limited systemic toxicity, and increased local concentrations of therapeutic regimens. Despite many advances, a great deal of work is still needed in the future to further characterize and optimize the various platforms. First of all, comparative studies are importantly required to identify what are the most advantageous materials (e.g. liposomes versus synthetic polymers etc.), sizes, compositions and other biophysical aspects, for each application. Few of this type of studies already appeared in the literature $[74,124,160]$ but a systematic classification is still lacking. Furthermore, comparative studies aimed at identifying the best synergistic combinations of immunomodulatory molecules (e.g. cytokines, chemotherapeutic agents, antigens etc.), coadjuvantes (e.g. TLR receptor ligands) and/ or target moieties (e.g. DC or T cell specific antibodies) will also help to progress the future of these therapies. Another key aspect to further investigate is the route of administration, in order to guarantee efficient delivery while limiting the treatment invasiveness. In this sense, a recent breakthrough study reported the successful use of MNs for the delivery of checkpoint inhibitors [159], a route of administration that should be further tested for the release of also different nanotherapies. Finally, apart from few cases, the majority of these formulations have not been implemented yet in the clinic. To this aim, studies in more sophisticated models such as "humanized" mouse models $[57,161]$ that better recapitulate the human settings of the disease will be key to support and boost future clinical translations. In conclusion, biomaterials constitute a powerful tool to overcome challenges with current immunotherapies, however we may have just started scratching the surface of the future bioengineered solutions for cancer immunotherapy.

\begin{abstract}
Abbreviations
ACT: adoptive T cell therapy; APC: antigen presenting cell; aAPC: artificial antigen presenting cell; CTC: circulating tumor cell; CTL: cytotoxic T lymphocyte; DC: dendritic cell; EPR: enhanced permeability and retention effect; GDR: galactosyl dextran-retinal; ICD: immunogenic cell death; TIL: infiltrated lymphocyte; MN: microneedle; PLGA: poly(lactic-co-glycolic acid); ROS: reactive oxygen species; TCR: T cell receptor; TLR: toll-like receptor; TAA: tumor associated antigen; WTL: whole tumor lysate.
\end{abstract}

\section{Authors' contributions}

CB wrote the section "Cancer vaccines", MG wrote the rest of the paper; LK and $\mathrm{H}$-AK conceived, supervised, reviewed and edited the manuscript. All authors read and approved the final manuscript.

\footnotetext{
Author details

${ }^{1}$ Center of Experimental Therapeutics, Department of Oncology, University Hospital of Lausanne, Lausanne, Switzerland. ${ }^{2}$ Laboratoire des Polymères, Institut des Matériaux and Institut des Sciences et Ingénierie Chimiques, École Polytechnique Fédérale de Lausanne (EPFL), Bâtiment MXD, Station 12, 1015 Lausanne, Switzerland. ${ }^{3}$ Ludwig Cancer Research Center, University of Lausanne, Lausanne, Switzerland.
}

Acknowledgements

Not applicable.

\section{Competing interests}

The authors declare that they have no competing interests.

Funding

This work was supported by the ISREC Foundation, thanks to a donation from the Biltema Foundation.

\section{Publisher's Note}

Springer Nature remains neutral with regard to jurisdictional claims in published maps and institutional affiliations.

Received: 11 May 2017 Accepted: 13 June 2017

Published online: 19 June 2017

\section{References}

1. McCarthy EF. The toxins of William B. Coley and the treatment of bone and soft-tissue sarcomas. Lowa Orthop J. 2006;26:154-8.

2. Kantoff PW, Higano CS, Shore ND, Berger ER, Small EJ, Penson DF, Redfern CH, Ferrari AC, Dreicer R, Sims RB, Xu Y, Frohlich MW, Schellhammer PF, IMPACT Study Investigators. Sipuleucel-T immunotherapy for castration-resistant prostate cancer. N Engl J Med. 2010;363:411-22.

3. D'Errico G, Machado HL, Sainz B. A current perspective on cancer immune therapy: step-by-step approach to constructing the magic bullet. Clin Transl Med. 2017;6:3.

4. Dunn GP, Old LJ, Schreiber RD. The three Es of cancer immunoediting. Annu Rev Immunol. 2004;22:329-60.

5. Kandalaft LE, Singh N, Liao JB, Facciabene A, Berek JS, Powell DJ, Coukos G. The emergence of immunomodulation: combinatorial immunochemotherapy opportunities for the next decade. Gynecol Oncol. 2010;116:222-33.

6. Casares N, Pequignot MO, Tesniere A, Ghiringhelli F, Roux S, Chaput N, Schmitt E, Hamai A, Hervas-Stubbs S, Obeid M, Coutant F, Métivier D, Pichard E, Aucouturier P, Pierron G, Garrido C, Zitvogel L, Kroemer G. Caspase-dependent immunogenicity of doxorubicin-induced tumor cell death. J Exp Med. 2005;202:1691-701.

7. Bobo D, Robinson KJ, Islam J, Thurecht KJ, Corrie SR. Nanoparticlebased medicines: a review of FDA-approved materials and clinical trials to date. Pharm Res. 2016;33:2373-87.

8. Matsumura Y, Maeda H. A new concept for macromolecular therapeutics in cancer chemotherapy: mechanism of tumoritropic accumulation of proteins and the antitumor agent smancs. Cancer Res. 1986;46:6387-92.

9. Danhier F. To exploit the tumor microenvironment: since the EPR effect fails in the clinic, what is the future of nanomedicine? I Control Release. 2016;244:108-21.

10. Zhao X, Yang K, Zhao R, Ji T, Wang X, Yang X, Zhang Y, Cheng K, Liu S, Hao J, Ren H, Leong KW, Nie G. Inducing enhanced immunogenic cell death with nanocarrier-based drug delivery systems for pancreatic cancer therapy. Biomaterials. 2016;102:187-97.

11. Zhao T, Ren H, Jia L, Chen J, Xin W, Yan F, Li J, Wang X, Gao S, Qian D, Huang C, Hao J. Inhibition of HIF-1a by PX-478 enhances the antitumor effect of gemcitabine by inducing immunogenic cell death in pancreatic ductal adenocarcinoma. Oncotarget. 2015;6:2250-62.

12. Kelland LR. Of mice and men: values and liabilities of the athymic nude mouse model in anticancer drug development. Eur I Cancer. 2004;40:827-36.

13. Lee S, Margolin K. Cytokines in cancer immunotherapy. Cancers (Basel). 2011;3:3856-93.

14. Zaharoff DA, Hoffman BS, Hooper HB, Benjamin CJ, Khurana KK, Hance KW, Rogers CJ, Pinto PA, Schlom J, Greiner JW. Intravesical immunotherapy of superficial bladder cancer with chitosan/interleukin-12. Cancer Res. 2009;69:6192-9.

15. Smith SG, Koppolu BP, Ravindranathan S, Kurtz SL, Yang L, Katz MD, Zaharoff DA. Intravesical chitosan/interleukin-12 immunotherapy 
induces tumor-specific systemic immunity against murine bladder cancer. Cancer Immunol Immunother. 2015;64:689-96.

16. Hallaj-Nezhadi S, Lotfipour F, Dass C. Nanoparticle-mediated interleukin-12 cancer gene therapy. J Pharm Pharm Sci. 2010;13:472-85.

17. Del Vecchio M, Bajetta E, Canova S, Lotze MT, Wesa A, Parmiani G, Anichini A. Interleukin-12: biological properties and clinical application. Clin Cancer Res. 2007;13:4677-85.

18. Yao H, Ng SS, Huo L-F, Chow BKC, Shen Z, Yang M, Sze J, Ko O, Li M, Yue A, Lu L-W, Bian X-W, Kung H-F, Lin MC. effective melanoma immunotherapy with interleukin-2 delivered by a novel polymeric nanoparticle. Mol Cancer Ther. 2011;10:1082-92.

19. Park J, Wrzesinski SH, Stern E, Look M, Criscione J, Ragheb R, Jay SM, Demento SL, Agawu A, Licona Limon P, Ferrandino AF, Gonzalez D, Habermann A, Flavell RA, Fahmy TM. Combination delivery of TGF- $\beta$ inhibitor and IL-2 by nanoscale liposomal polymeric gels enhances tumour immunotherapy. Nat Mater. 2012;11:895-905.

20. Frick SU, Domogalla MP, Baier G, Wurm FR, Mailänder V, Landfester K, Steinbrink K. Interleukin-2 functionalized nanocapsules for T cell-based immunotherapy. ACS Nano. 2016;10:9216-26.

21. Hong E, Usiskin IM, Bergamaschi C, Hanlon DJ, Edelson RL, Justesen $\mathrm{S}$, Pavlakis GN, Flavell RA, Fahmy TM. Configuration-dependent Presentation of Multivalent IL-15:IL-15Ra Enhances the Antigen-specific T cell response and anti-tumor immunity. J Biol Chem. 2016;291:8931-50.

22. Pradhan P, Qin H, Leleux JA, Gwak D, Sakamaki I, Kwak LW, Roy K. The effect of combined ILIO siRNA and CpG ODN as pathogenmimicking microparticles on Th1/Th2 cytokine balance in dendritic cells and protective immunity against B cell lymphoma. Biomaterials. 2014;35:5491-504.

23. Vanitha S, Chaubey N, Ghosh SS, Sanpui P. Recombinant human granulocyte macrophage colony stimulating factor (hGM-CSF): Possibility of nanoparticle-mediated delivery in cancer immunotherapy. Bioengineered. 2016;8:1-4.

24. Vanitha S, Goswami U, Chaubey N, Ghosh SS, Sanpui P. Functional characterization of recombinant human granulocyte colony stimulating factor (hGMCSF) immobilized onto silica nanoparticles. Biotechnol Lett. 2016;38:243-9.

25. Zhang Y, Cui Z, Kong H, Xia K, Pan L, Li J, Sun Y, Shi J, Wang L, Zhu Y, Fan C. One-shot immunomodulatory nanodiamond agents for cancer immunotherapy. Adv Mater. 2016;28:2699-708.

26. De Titta A, Ballester M, Julier Z, Nembrini C, Jeanbart L, van der Vlies AJ, Swartz MA, Hubbell JA. Nanoparticle conjugation of $\mathrm{CpG}$ enhances adjuvancy for cellular immunity and memory recall at low dose. Proc Natl Acad Sci. 2013;1 10:19902-7.

27. Thomas SN, Vokali E, Lund AW, Hubbell JA, Swartz MA. Targeting the tumor-draining lymph node with adjuvanted nanoparticles reshapes the anti-tumor immune response. Biomaterials. 2014;35:814-24.

28. Ramani M, Mudge MC, Morris RT, Zhang Y, Warcholek SA, Hurst MN, Riviere JE, DeLong RK. Zinc oxide nanoparticle-poly I:C RNA complexes: Implication as therapeutics against experimental melanoma. Mol Pharm. 2017;14:614-25. doi: 10.1021/acs. molpharmaceut.6b00795

29. Hafner AM, Corthésy B, Merkle HP. Particulate formulations for the delivery of poly $(\mathrm{l}: \mathrm{C})$ as vaccine adjuvant. Adv Drug Deliv Rev. 2013;65:1386-99.

30. Gammon JM, Dold NM, Jewell CM. Improving the clinical impact of biomaterials in cancer immunotherapy. Oncotarget. 2016;7:15421-43.

31. Lu Y, Wang Y, Miao L, Haynes M, Xiang G, Huang L. Exploiting in situ antigen generation and immune modulation to enhance chemotherapy response in advanced melanoma: a combination nanomedicine approach. Cancer Lett. 2016;379:32-8.

32. Lim YT, Heo MB, Kim S-Y, Yun W. Sequential delivery of an anticancer drug and combined immunomodulatory nanoparticles for efficient chemoimmunotherapy. Int J Nanomed. 2015;10:5981.

33. Roy A, Singh MS, Upadhyay P, Bhaskar S. Nanoparticle mediated codelivery of paclitaxel and a TLR-4 agonist results in tumor regression and enhanced immune response in the tumor microenvironment of a mouse model. Int J Pharm. 2013;445:171-80.

34. Roy A, Chandra S, Mamilapally S, Upadhyay P, Bhaskar S. Anticancer and immunostimulatory activity by conjugate of paclitaxel and non-toxic derivative of LPS for combined chemo-immunotherapy. Pharm Res. 2012;29:2294-309.
35. Jehn CF, Hemmati P, Lehenbauer-Dehm S, Kümmel S, Flath B, Schmid P. Biweekly pegylated liposomal doxorubicin (Caelyx) in heavily pretreated metastatic breast cancer: a phase 2 study. Clin Breast Cancer. 2016;16:514-9.

36. Rom J, Bechstein S, Domschke C, Golatta M, Mayer C, Heil J, Thum J, Smetanay K, Windemuth-Kieselbach C, Wallwiener M, Marme F, Schuetz F, Sohn C, Schneeweiss A. Efficacy and toxicity profile of pegylated liposomal doxorubicin (Caelyx) in patients with advanced breast cancer. Anticancer Drugs. 2014;25:219-24.

37. Vergote I, Schilder RJ, Pippitt CH, Wong S, Gordon AN, Scudder S, Kridelka F, Dirix L, Leach JW, Ananda S, Nanayakkara N, Melara R, Bass MB, Litten J, Adewoye H, Wenham RM. A phase $1 \mathrm{~b}$ study of trebananib in combination with pegylated liposomal doxorubicin or topotecan in women with recurrent platinum-resistant or partially platinum-sensitive ovarian cancer. Gynecol Oncol. 2014;135:25-33.

38. Gordon AN, Fleagle JT, Guthrie D, Parkin DE, Gore ME, Lacave AJ. Recurrent epithelial ovarian carcinoma: a randomized phase III study of pegylated liposomal doxorubicin versus topotecan. J Clin Oncol. 2001;19:3312-22.

39. Swenson CE, Bolcsak LE, Batist G, Guthrie TH, Tkaczuk KH, Boxenbaum H, Welles L, Chow S-C, Bhamra R, Chaikin P. Pharmacokinetics of doxorubicin administered iv as Myocet (TLC D-99; liposome-encapsulated doxorubicin citrate) compared with conventional doxorubicin when given in combination with cyclophosphamide in patients with metastatic breast cancer. Anticancer Drugs. 2003;14:239-46.

40. Leonard RCF, Williams S, Tulpule A, Levine AM, Oliveros S. Improving the therapeutic index of anthracycline chemotherapy: focus on liposomal doxorubicin $\left(\right.$ Myocet $^{\mathrm{TMM}}$ ). Breast. 2009;18:218-24.

41. Eitan R, Fishman A, Meirovitz M, Goldenberg H, Amit A, Koren C, Schneider Y, Rosengarten O, Neuman A, Keren-Rosenberg S, Safra T. Liposome-encapsulated doxorubicin citrate (Myocet) for treatment of recurrent epithelial ovarian cancer. Anticancer Drugs. 2014;25:101-5.

42. Lowis $\mathrm{S}$, Lewis I, Elsworth A, Weston C, Doz F, Vassal G, Bellott R, Robert J, Pein F, Ablett S, Pinkerton R, Frappaz D, United Kingdom Children's Cancer Study Group (UKCCSG) New Agents, and Société Française d'Oncologie Pédiatrique (SFOP) Pharmacology Group. A phase I study of intravenous liposomal daunorubicin (DaunoXome) in paediatric patients with relapsed or resistant solid tumours. Br J Cancer. 2006;95:571-80.

43. McTiernan A, Whelan J, Leahy M, Woll PJ, Judson I. A phase II nonrandomised open-label study of liposomal daunorubicin (DaunoXome) in advanced soft tissue sarcoma. Sarcoma. 2006;2006:1-5.

44. Passero FC Jr, Grapsa D, Syrigos KN, Saif MW. The safety and efficacy of Onivyde (irinotecan liposome injection) for the treatment of metastatic pancreatic cancer following gemcitabine-based therapy. Expert Rev Anticancer Ther. 2016. doi:10.1080/14737140.2016.1192471.

45. Silverman JA, Deitcher SR. Marqibo ${ }^{\circledR}$ (vincristine sulfate liposome injection) improves the pharmacokinetics and pharmacodynamics of vincristine. Cancer Chemother Pharmacol. 2013;71:555-64.

46. Shah NN, Merchant MS, Cole DE, Jayaprakash N, Bernstein D, Delbrook C, Richards K, Widemann BC, Wayne AS. Vincristine sulfate liposomes injection (VSLI, Marqibo ${ }^{\circledR}$ ): results from a phase I study in children, adolescents, and young adults with refractory solid tumors or leukemias. Pediatr Blood Cancer. 2016;63:997-1005.

47. Kaplan LD, Deitcher SR, Silverman JA, Morgan G. Phase Il study of vincristine sulfate liposome injection (Marqibo) and Rituximab for patients with relapsed and refractory diffuse large B-Cell lymphoma or mantle cell lymphoma in need of palliative therapy. Clin Lymphoma Myeloma Leuk. 2014;14:37-42.

48. Hagemeister F, Rodriguez MA, Deitcher SR, Younes A, Fayad L, Goy A, Dang NH, Forman A, McLaughlin P, Medeiros LJ, Pro B, Romaguera J, Samaniego F, Silverman JA, Sarris A, Cabanillas F. Long term results of a phase 2 study of vincristine sulfate liposome injection (Marqibo ${ }^{\circledR}$ ) substituted for non-liposomal vincristine in cyclophosphamide, doxorubicin, vincristine, prednisone with or without rituximab for patients with untreated aggressive. Br J Haematol. 2013;162:631-8.

49. Zong Y, Wu J, Shen K. Nanoparticle albumin-bound paclitaxel as neoadjuvant chemotherapy of breast cancer: a systematic review and meta-analysis. Oncotarget. 2015;8:17360

50. Schettini F, Giuliano M, De Placido S, Arpino G. Nab-paclitaxel for the treatment of triple-negative breast cancer: rationale, clinical data and future perspectives. Cancer Treat Rev. 2016;50:129-41. 
51. Leon-Ferre RA, Markovic SN. Nab-paclitaxel in patients with metastatic melanoma. Expert Rev Anticancer Ther. 2015;15:1371-7.

52. Blair HA, Deeks ED. Albumin-bound paclitaxel: a review in non-small cell lung cancer. Drugs. 2015;75:2017-24.

53. Alrwas A, Papadopoulos NE, Cain S, Patel SP, Kim KB, Deburr TL, Bassett R, Hwu W-J, Bedikian AY, Davies MA, Woodman SE, Hwu P, Hwu P. Phase I trial of biochemotherapy with cisplatin, temozolomide, and dose escalation of nab-paclitaxel combined with interleukin-2 and interferon-a in patients with metastatic melanoma. Melanoma Res. 2014;24:342-8.

54. Adams S, Diamond J, Hamilton E, Pohlmann P, Tolaney S, Molinero L, He X, Waterkamp D, Funke R, Powderly J. Phase Ib trial of atezolizumab in combination with nab-paclitaxel in patients with metastatic triplenegative breast cancer (mTNBC)., in 2016 ASCO Annual Meeting. 2016.

55. Simpkins F, Flores A, Chu C, Berek JS, Lucci J, Murray S, Bauman J, Struemper H, Germaschewski F, Jonak Z, Gardner O, Toso J, Coukos G. Chemoimmunotherapy using pegylated liposomal doxorubicin and interleukin-18 in recurrent ovarian cancer: a phase I dose-escalation study. Cancer Immunol Res. 2013;1:168-78.

56. Dijkgraaf EM, Santegoets SJAM, Reyners AKL, Goedemans R, Wouters MCA, Kenter GG, van Erkel AR, van Poelgeest MIE, Nijman HW, van der Hoeven JJM, Welters MJP, van der Burg SH, Kroep JR. A phase I trial combining carboplatin/doxorubicin with tocilizumab, an anti-IL-6R monoclonal antibody, and interferon-a2b in patients with recurrent epithelial ovarian cancer. Ann Oncol. 2015:26:2141-9.

57. Zhou Q, Facciponte J, Jin M, Shen Q, Lin Q. Humanized NOD-SCID IL2rg-/- mice as a preclinical model for cancer research and its potential use for individualized cancer therapies. Cancer Lett. 2014;344:13-9.

58. Soliman $\mathrm{H}$. <em $>$ nab $</$ em $>$-Paclitaxel as a potential partner with checkpoint inhibitors in solid tumors. Onco Targets Ther. 2016;10:101-12.

59. Rosenberg SA, Restifo NP. Adoptive cell transfer as personalized immunotherapy for human cancer. Science (80-.). 2015;348:62-8.

60. Duong CPM, Yong CSM, Kershaw MH, Slaney CY, Darcy PK. Cancer immunotherapy utilizing gene-modified T cells: from the bench to the clinic. Mol Immunol. 2015;67:46-57.

61. Besser MJ, Shapira-Frommer R, Itzhaki O, Treves AJ, Zippel DB, Levy D, Kubi A, Shoshani N, Zikich D, Ohayon Y, Ohayon D, Shalmon B, Markel G, Yerushalmi R, Apter S, Ben-Nun A, Ben-Ami E, Shimoni A, Nagler A, Schachter J. Adoptive transfer of tumor-infiltrating lymphocytes in patients with metastatic melanoma: intent-to-treat analysis and efficacy after failure to prior immunotherapies. Clin Cancer Res. 2013;19:4792-800.

62. Morgan RA, Dudley ME, Wunderlich JR, Hughes MS, Yang JC, Sherry RM, Royal RE, Topalian SL, Kammula US, Restifo NP, Zheng Z, Nahvi A, de Vries CR, Rogers-Freezer LJ, Mavroukakis SA, Rosenberg SA. Cancer regression in patients after transfer of genetically engineered lymphocytes. Science (80-.). 2006;314:126-9.

63. Johnson LA, Morgan RA, Dudley ME, Cassard L, Yang JC, Hughes MS, Kammula US, Royal RE, Sherry RM, Wunderlich JR, Lee C-CR, Restifo NP, Schwarz SL, Cogdill AP, Bishop RJ, Kim H, Brewer CC, Rudy SF, Van Waes C, Davis JL, Mathur A, Ripley RT, Nathan DA, Laurencot CM, Rosenberg SA. Gene therapy with human and mouse T-cell receptors mediates cancer regression and targets normal tissues expressing cognate antigen. Blood. 2009;114:535-46.

64. Kochenderfer JN, Wilson WH, Janik JE, Dudley ME, Stetler-Stevenson M, Feldman SA, Maric I, Raffeld M, Raffeld M, Nathan D-AN, Lanier BJ, Morgan RA, Rosenberg SA. Eradication of B-lineage cells and regression of lymphoma in a patient treated with autologous T cells genetically engineered to recognize CD19. Blood. 2010;116:4099-102.

65. Robbins PF, Morgan RA, Feldman SA, Yang JC, Sherry RM, Dudley ME, Wunderlich JR, Nahvi AV, Helman LJ, Mackall CL, Kammula US, Hughes MS, Restifo NP, Raffeld M, Lee C-CR, Levy CL, Li YF, El-Gamil M, Schwarz SL, Laurencot C, Rosenberg SA. Tumor regression in patients with metastatic synovial cell sarcoma and melanoma using genetically engineered lymphocytes reactive with NY-ESO-1. J Clin Oncol. 2011;29:917-24.

66. Maude SL, Frey N, Shaw PA, Aplenc R, Barrett DM, Bunin NJ, Chew A Gonzalez VE, Zheng Z, Lacey SF, Mahnke YD, Melenhorst JJ, Rheingold SR, Shen A, Teachey DT, Levine BL, June CH, Porter DL, Grupp SA. Chimeric antigen receptor $T$ Cells for sustained remissions in leukemia. N Engl J Med. 2014;371:1507-17.
67. Stephan MT, Moon JJ, Um SH, Bershteyn A, Irvine DJ. Therapeutic cell engineering with surface-conjugated synthetic nanoparticles. Nat Med. 2010;16:1035-41.

68. Stephan MT, Stephan SB, Bak P, Chen J, Irvine DJ. Synapse-directed delivery of immunomodulators using T-cell-conjugated nanoparticles. Biomaterials. 2012;33:5776-87.

69. Zheng Y, Stephan MT, Gai SA, Abraham W, Shearer A, Irvine DJ. In vivo targeting of adoptively transferred T-cells with antibody- and cytokineconjugated liposomes. J Control Release. 2013;172:426-35.

70. Smith TT, Stephan SB, Moffett HF, McKnight LE, Ji W, Reiman D, Bonagofski E, Wohlfahrt ME, Pillai SPS, Stephan MT. In situ programming of leukaemia-specific T cells using synthetic DNA nanocarriers. Nat. Nanotechnol. 2017. doi:10.1038/nnano.2017.57.

71. Smith-Garvin JE, Koretzky GA, Jordan MS. T cell activation. Annu Rev Immunol. 2009;27:591-619.

72. Steenblock ER, Fahmy TM. A comprehensive platform for ex vivo T-cell expansion based on biodegradable polymeric artificial antigen-presenting cells. Mol Ther. 2008:16:765-72.

73. Perica K, De León Medero A, Durai M, Chiu YL, Bieler JG, Sibener L, Niemöller M, Assenmacher M, Richter A, Edidin M, Oelke M, Schneck J. Nanoscale artificial antigen presenting cells for $T$ cell immunotherapy. Nanomedicine. 2014:10:119-29.

74. Manolova V, Flace A, Bauer M, Schwarz K, Saudan P, Bachmann MF. Nanoparticles target distinct dendritic cell populations according to their size. Eur J Immunol. 2008;38:1404-13.

75. Perica K, Bieler JG, Schütz C, Varela JC, Douglass J, Skora A, Chiu YL, Oelke M, Kinzler K, Zhou S, Vogelstein B, Schneck JP. Enrichment and expansion with nanoscale artificial antigen presenting cells for adoptive immunotherapy. ACS Nano. 2015;9:6861-71.

76. Sunshine JC, Perica K, Schneck JP, Green JJ. Particle shape dependence of CD8+ T cell activation by artificial antigen presenting cells. Biomaterials. 2014;35:269-77.

77. Kumari S, Curado S, Mayya V, Dustin ML. T cell antigen receptor activation and actin cytoskeleton remodeling. Biochim Biophys Acta Biomembr. 2014;1838:546-56.

78. Perica K, Kosmides AK, Schneck JP. Linking form to function: biophysical aspects of artificial antigen presenting cell design. Biochim Biophys Acta Mol Cell Res. 2015;1853:781-90.

79. Gottschalk RA, Hathorn MM, Beuneu H, Corse E, Dustin ML, Altan-Bonnet G, Allison JP. Distinct influences of peptide-MHC quality and quantity on in vivo T-cell responses. Proc Natl Acad Sci USA. 2012;109:881-6.

80. Gottschalk RA, Corse E, Allison JP. TCR ligand density and affinity determine peripheral induction of Foxp3 in vivo. J Exp Med. 2010:207:1701-11.

81. Shen K, Thomas VK, Dustin ML, Kam LC. Micropatterning of costimulatory ligands enhances CD4+ T cell function. Proc Natl Acad Sci. 2008;105:7791-6.

82. Uyl-de Groot CA, Vermorken JB, Hanna MG, Verboom P, Groot MT, Bonsel GJ, Meijer CJLM, Pinedo HM. Immunotherapy with autologous tumor cell-BCG vaccine in patients with colon cancer: a prospective study of medical and economic benefits. Vaccine. 2005:23:2379-87.

83. Hoover HC, Brandhorst JS, Peters LC, Surdyke MG, Takeshita Y, Madariaga J, Muenz LR, Hanna MG. Adjuvant active specific immunotherapy for human colorectal cancer: 6.5-year median follow-up of a phase III prospectively randomized trial. J Clin Oncol. 1993;11:390-9.

84. Jonasch E, Wood C, Tamboli P, Pagliaro LC, Tu SM, Kim J, Srivastava P, Perez C, Isakov L, Tannir N. Vaccination of metastatic renal cell carcinoma patients with autologous tumour-derived vitespen vaccine: clinical findings. Br J Cancer. 2008;98:1336-41.

85. Ophir E, Bobisse S, Coukos G, Harari A, Kandalaft LE. Personalized approaches to active immunotherapy in cancer. Biochim Biophys Acta Rev Cancer. 2016;1865:72-82.

86. Bonab F, Khansari S, Khansari N. Dendritic cell vaccine and its application in cancer therapy. Int J Vaccines Vaccin. 2015;1:5-9.

87. Jäger E, Ringhoffer M, Karbach J, Arand M, Oesch F, Knuth A. Inverse relationship of melanocyte differentiation antigen expression in melanoma tissues and CD8+ cytotoxic-T-cell responses: evidence for immunoselection of antigen-loss variants in vivo. Int J Cancer. 1996;66:470-6.

88. Chiang CLL, Hagemann AR, Leskowitz R, Mick R, Garrabrant T, Czerniecki BJ, Kandalaft LE, Powell DJ, Coukos G. Day-4 myeloid dendritic cells 
pulsed with whole tumor lysate are highly immunogenic and elicit potent anti-tumor responses. PLoS ONE. 2011;6:e28732.

89. Mahdian R, Kokhaei P, Najar HM, Derkow K, Choudhury A, Mellstedt H. Dendritic cells, pulsed with lysate of allogeneic tumor cells, are capable of stimulating MHC-restricted antigen-specific antitumor T cells. Med Oncol. 2006;23:273-82.

90. Yu JS, Liu G, Ying H, Yong WH, Black KL, Wheeler CJ. Vaccination with tumor lysate-pulsed dendritic cells elicits antigen-specific, cytotoxic T-cells in patients with malignant glioma. Cancer Res. 2004;64:4973-9.

91. Geiger JD, Hutchinson RJ, Hohenkirk LF, Mckenna EA, Yanik GA, Levine JE, Chang AE, Braun TM, Mule JJ. Vaccination of pediatric solid tumor patients with tumor lysate-pulsed dendritic cells can expand specific TCells and mediate tumor regression vaccination of pediatric solid tumor patients with tumor lysate-pulsed dendritic cells can expand specific T cell. Cancer Res. 2011;61:8513-9.

92. Kandalaft LE, Chiang CL, Tanyi J, Motz G, Balint K, Mick R, Coukos G. A phase I vaccine trial using dendritic cells pulsed with autologous oxidized lysate for recurrent ovarian cancer. J TransI Med. 2013;11:149.

93. Chiang CL, Kandalaft LE, Tanyi J, Hagemann AR, Motz GT, Svoronos N, Montone K, Mantia-Smaldone GM, Nisenbaum HL, Levine BL, Kalos M, Czerniecki BJ, Drew A, Powell DJ Jr, Mick R, Smith L, Coukos G. A dendritic cell vaccine pulsed with autologous hypochlorous acid-oxidized ovarian cancer lysate primes effective broad antitumor immunity: from bench to bedside. Clin Cancer Res. 2013;19(17):4801-15. doi:10.1158/1078-0432.CCR-13-1185.

94. Kim HS, Choo YS, Koo T, Bang S, Oh TY, Wen J, Song SY. Enhancement of antitumor immunity of dendritic cells pulsed with heat-treated tumor lysate in murine pancreatic cancer. Immunol Lett. 2006;103:142-8.

95. Mogrão J, da Costa CA, Gaspar R, Florindo HF. Modulation of dendritic cells by nanotechnology-based immunotherapeutic strategies. J Biomed Nanotechnol. 2016;12:405-34.

96. North SA, Graham K, Bodnar D, Venner P. A pilot study of the liposomal MUC1 vaccine BLP25 in prostate specific antigen failures after radical prostatectomy. J Urol. 2006;176:91-5.

97. Palmer M, Parker J, Modi S, Butts C, Smylie M, Meikle A, Kehoe M, MacLean G, Longenecker M. Phase I study of the BLP25 (MUC1 Peptide) liposomal vaccine for active specific immunotherapy in stage IIIB/IV non-small-cell lung cancer. Clin Lung Cancer. 2001;3:49-57.

98. Kranz LM, Diken M, Haas H, Kreiter S, Loquai C, Reuter KC, Meng M, Fritz D, Vascotto F, Hefesha H, Grunwitz C, Vormehr M, Hüsemann Y, Selmi A, Kuhn AN, Buck J, Derhovanessian E, Rae R, Attig S, Diekmann J, Jabulowsky RA, Heesch S, Hassel J, Langguth P, Grabbe S, Huber C, Türeci Ö, Sahin U. Systemic RNA delivery to dendritic cells exploits antiviral defence for cancer immunotherapy. Nature. 2016;534:396-401.

99. Berinstein NL, Karkada M, Morse MA, Nemunaitis JJ, Chatta G, Kaufman H, Odunsi K, Nigam R, Sammatur L, MacDonald LD, Weir GM, Stanford MM, Mansour M. First-in-man application of a novel therapeutic cancer vaccine formulation with the capacity to induce multi-functional $T$ cell responses in ovarian, breast and prostate cancer patients. J Transl Med. 2012;10:156.

100. Berinstein NL, Karkada M, Oza AM, Odunsi K, Villella JA, Nemunaitis JJ, Morse MA, Pejovic T, Bentley J, Buyse M, Nigam R, Weir GM, MacDonald LD, Quinton T, Rajagopalan R, Sharp K, Penwell A, Sammatur L, Burzykowski T, Stanford MM, Mansour M. Survivin-targeted immunotherapy drives robust polyfunctional $\mathrm{T}$ cell generation and differentiation in advanced ovarian cancer patients. Oncoimmunology. 2015;4:e1026529.

101. Sangha R, Butts C. L-BLP25: a peptide vaccine strategy in non small cell lung cancer. Clin Cancer Res. 2007;13:54652-4.

102. Bedikian AY, Richards J, Kharkevitch D, Atkins MB, Whitman E, Gonzalez R. A phase 2 study of high-dose Allovectin-7 in patients with advanced metastatic melanoma. Melanoma Res. 2010;20:218-26.

103. Butts C, Socinski MA, Mitchell PL, Thatcher N, Havel L, Krzakowski M, Nawrocki S, Ciuleanu T-E, Bosquée L, Trigo JM, Spira A, Tremblay L, Nyman J, Ramlau R, Wickart-Johansson G, Ellis P, Gladkov O, Pereira JR, Eberhardt WEE, Helwig C, Schröder A, Shepherd FA. Tecemotide (L-BLP25) versus placebo after chemoradiotherapy for stage III nonsmall-cell lung cancer (START): a randomised, double-blind, phase 3 trial. Lancet Oncol. 2014;15:59-68.

104. Williams R. Discontinued in 2013: oncology drugs. Expert Opin Investig Drugs. 2015;24:95-110.
105. Krishnamachari Y, Geary SM, Lemke CD, Salem AK. Nanoparticle delivery systems in cancer vaccines. Pharm Res. 2011;28:215-36.

106. Cruz LJ, Rosalia RA, Kleinovink JW, Rueda F, Löwik CWGM, Ossendorp F. Targeting nanoparticles to CD40, DEC-205 or CD 1 1 c molecules on dendritic cells for efficient CD8 + T cell response: a comparative study. J Control Release. 2014;192:209-18.

107. Hamdy S, Haddadi A, Shayeganpour A, Samuel J, Lavasanifar A. Activation of antigen-specific T cell-responses by mannan-decorated PLGA nanoparticles. Pharm Res. 2011;28:2288-301.

108. Hamdy S, Molavi O, Ma Z, Haddadi A, Alshamsan A, Gobti Z, Elhasi S, Samuel J, Lavasanifar A. Co-delivery of cancer-associated antigen and Toll-like receptor 4 ligand in PLGA nanoparticles induces potent CD8+T cell-mediated anti-tumor immunity. Vaccine. 2008;26:5046-57.

109. Zhang Z, Tongchusak S, Mizukami Y, Kang YJ, loji T, Touma M, Reinhold B, Keskin DB, Reinherz EL, Sasada T. Induction of anti-tumor cytotoxic T cell responses through PLGA-nanoparticle mediated antigen delivery. Biomaterials. 2011;32:3666-78.

110. Prasad S, Cody V, Saucier-Sawyer JK, Saltzman WM, Sasaki CT, Edelson RL, Birchall MA, Hanlon DJ. Polymer nanoparticles containing tumor lysates as antigen delivery vehicles for dendritic cell-based antitumor immunotherapy. Nanomedicine. 2011;7:1-10.

111. Prasad S, Cody V, Saucier-Sawyer JK, Fadel TR, Edelson RL, Birchall MA, Hanlon DJ. Optimization of stability, encapsulation, release, and crosspriming of tumor antigen-containing PLGA nanoparticles. Pharm Res. 2012:29:2565-77.

112. Mueller M, Reichardt W, Koerner J, Groettrup M. Coencapsulation of tumor lysate and CpG-ODN in PLGA-microspheres enables successful immunotherapy of prostate carcinoma in TRAMP mice. J Control Release. 2012;162:159-66.

113. Iranpour S, Nejati V, Delirezh N, Biparva P, Shirian S. Enhanced stimulation of anti-breast cancer $T$ cells responses by dendritic cells loaded with poly lactic-co-glycolic acid (PLGA) nanoparticle encapsulated tumor antigens. J Exp Clin Cancer Res. 2016;35:168.

114. Kageyama S, Wada H, Muro K, Niwa Y, Ueda S, Miyata H, Takiguchi S, Sugino SH, Miyahara Y, Ikeda H, Imai N, Sato E, Yamada T, Osako M, Ohnishi M, Harada N, Hishida T, Doki Y, Shiku H. Dose-dependent effects of NY-ESO-1 protein vaccine complexed with cholesteryl pullulan (CHPNY-ESO-1) on immune responses and survival benefits of esophageal cancer patients. J TransI Med. 2013;11:246.

115. Kitano S, Kageyama S, Nagata Y, Miyahara Y, Hiasa A, Naota H, Okumura S, Imai H, Shiraishi T, Masuya M, Nishikawa M, Sunamoto J, Akiyoshi K, Kanematsu T, Scott AM, Murphy R, Hoffman EW, Old LJ, Shiku H. HER2specifict-cell immune responses in patients vaccinated with truncated HER2 protein complexed with nanogels of cholesteryl pullulan. Clin Cancer Res. 2006:12:7397-405.

116. Kageyama S, Kitano S, Hirayama M, Nagata Y, Imai H, Shiraishi T, Akiyoshi K, Scott AM, Murphy R, Hoffman EW, Old LJ, Katayama N, Shiku H. Humoral immune responses in patients vaccinated with 1-146 HER2 protein complexed with cholesteryl pullulan nanogel. Cancer Sci. 2008;99:601-7.

117. Shi G-N, Zhang C-N, Xu R, Niu J-F, Song H-J, Zhang X-Y, Wang W-W, Wang Y-M, Li C, Wei X-Q, Kong D-L. Enhanced antitumor immunity by targeting dendritic cells with tumor cell lysate-loaded chitosan nanoparticles vaccine. Biomaterials. 2017;113:191-202.

118. Rosalia RA, Cruz LJ, van Duikeren S, Tromp AT, Silva AL, Jiskoot W, de Gruij T, Löwik C, Oostendorp J, van der Burg SH, Ossendorp F. CD40targeted dendritic cell delivery of PLGA-nanoparticle vaccines induce potent anti-tumor responses. Biomaterials. 2015;40:88-97.

119. Saluja SS, Hanlon DJ, Sharp FA, Hong E, Khalil D, Robinson E, Tigelaar R, Fahmy TM, Edelson RL. Targeting human dendritic cells via DEC-205 using PLGA nanoparticles leads to enhanced cross-presentation of a melanoma-associated antigen. Int J Nanomed. 2014;9:5231-46.

120. Walters AA, Somavarapu S, Riitho V, Stewart GR, Charleston B, Steinbach F, Graham SP. Assessment of the enhancement of PLGA nanoparticle uptake by dendritic cells through the addition of natural receptor ligands and monoclonal antibody. Vaccine. 2015;33:6588-95.

121. Sehgal K, Ragheb R, Fahmy TM, Dhodapkar MV, Dhodapkar KM. Nanoparticle-mediated combinatorial targeting of multiple human dendritic cell (DC) subsets leads to enhanced T cell activation via IL15-dependent DC crosstalk. J Immunol. 2014;193:2297-305. 
122. Cruz LJ, Tacken PJ, Pots JM, Torensma R, Buschow SI, Figdor CG. Comparison of antibodies and carbohydrates to target vaccines to human dendritic cells via DC-SIGN. Biomaterials. 2012;33:4229-39.

123. Zaks K, Jordan M, Guth A, Sellins K, Kedl R, Izzo A, Bosio C, Dow S. Efficient immunization and cross-priming by vaccine adjuvants containing TLR3 or TLR9 agonists complexed to cationic liposomes. J Immunol. 2006:176:7335-45.

124. Stone GW, Barzee S, Snarsky V, Santucci C, Tran B, Langer R, Zugates GT, Anderson DG, Kornbluth RS. Nanoparticle-delivered multimeric soluble CD40L DNA combined with toll-like receptor agonists as a treatment for melanoma. PLoS ONE. 2009:4:e7334.

125. Joffre OP, Segura E, Savina A, Amigorena S. Cross-presentation by dendritic cells. Nat Rev Immunol. 2012:12:557-69.

126. Yuba E, Harada A, Sakanishi Y, Watarai S, Kono K. A liposome-based antigen delivery system using $\mathrm{pH}$-sensitive fusogenic polymers for cancer immunotherapy. Biomaterials. 2013;34:3042-52.

127. Yuba E, Kono Y, Harada A, Yokoyama S, Arai M, Kubo K, Kono K. The application of $\mathrm{pH}$-sensitive polymer-lipids to antigen delivery for cancer immunotherapy. Biomaterials. 2013;34:5711-21.

128. Yoshizaki Y, Yuba E, Sakaguchi N, Koiwai K, Harada A, Kono K. Potentiation of $\mathrm{pH}$-sensitive polymer-modified liposomes with cationic lipid inclusion as antigen delivery carriers for cancer immunotherapy. Biomaterials. 2014;35:8186-96.

129. Ruff LE, Mahmoud EA, Sankaranarayanan J, Morachis JM, Katayama CD, Corr M, Hedrick SM, Almutairi A. Antigen-loaded pH-sensitive hydrogel microparticles are taken up by dendritic cells with no requirement for targeting antibodies. Integr Biol (Camb). 2013;5:195-203.

130. Keller S, wilson JT, Patilea GI, Kern HB, Convertine AJ, Stayton PS. Neutral polymer micelle carriers with $\mathrm{pH}$-responsive, endosome-releasing activity modulate antigen trafficking to enhance CD8 $+\mathrm{T}$ cell responses. J Control Release. 2014;191:24-33.

131. Wilson JT, Keller S, Manganiello MJ, Cheng C, Lee C-C, Opara C, Convertine A, Stayton PS. pH-responsive nanoparticle vaccines for dual-delivery of antigens and immunostimulatory oligonucleotides. ACS Nano. 2013;7:3912-25.

132. Wilson JT, Postma A, Keller S, Convertine AJ, Moad G, Rizzardo E, Meagher L, Chiefari J, Stayton PS. Enhancement of MHC-I antigen presentation via architectural control of pH-responsive, endosomolytic polymer nanoparticles. AAPS J. 2015;17:358-69.

133. Wang C, Li P, Liu L, Pan H, Li H, Cai L, Ma Y. Self-adjuvanted nanovaccine for cancer immunotherapy: role of lysosomal rupture-induced ROS in MHC class I antigen presentation. Biomaterials. 2016;79:88-100.

134. Masuda T, Hayashi N, Iguchi T, Ito S, Eguchi H, Mimori K. Clinical and biological significance of circulating tumor cells in cancer. Mol Oncol. 2016;10:408-17

135. Ashworth TR. A case of cancer in which similar cells similar to those in the tumour were seen in the blood after death. Aust Med J. 1869;14:146-9.

136. Allard WJ, Matera J, Miller MC, Repollet M, Connelly MC, Rao C, Tibbe AGJ, Uhr JW, Terstappen LWMM. Tumor cells circulate in the periphera blood of all major carcinomas but not in healthy subjects or patients with nonmalignant diseases. Clin Cancer Res. 2004;10:6897-904.

137. Armstrong AJ, Marengo MS, Oltean S, Kemeny G, Bitting RL, Turnbul JD, Herold Cl, Marcom PK, George DJ, Garcia-Blanco MA. Circulating tumor cells from patients with advanced prostate and breast cancer display both epithelial and mesenchymal markers. Mol Cancer Res. 2011:9:997-1007.

138. Massard C, Oulhen M, Le Moulec S, Auger N, Foulon S, Abou-Lovergne A, Billiot F, Valent A, Marty V, Loriot Y, Fizazi K, Vielh P, Farace F. Phenotypic and genetic heterogeneity of tumor tissue and circulating tumor cells in patients with metastatic castration resistant prostate cancer: a report from the PETRUS prospective study. Oncotarget. 2016;7:55069-82.

139. McDaniel AS, Ferraldeschi R, Krupa R, Landers M, Graf R, Louw J, Jendrisak A, Bales N, Marrinucci D, Zafeiriou Z, Flohr P, Sideris S, Crespo M, Figueiredo I, Mateo J, de Bono JS, Dittamore R, Tomlins SA, Attard G. Phenotypic diversity of circulating tumour cells in patients with metastatic castration-resistant prostate cancer. BJU Int. 2016. doi:10.1111/ bju.13631.

140. Bhana S, Wang Y, Huang X. Nanotechnology for enrichment and detection of circulating tumor cells. Nanomedicine. 2015;10:1973-90.
141. Yoon HJ, Kozminsky M, Nagrath S. Emerging role of nanomaterials in circulating tumor cell isolation and analysis. ACS Nano. 2014;8:1995-2017.

142. Myung JH, Tam KA, Park S, Cha A, Hong S. Recent advances in nanotechnology-based detection and separation of circulating tumor cells. Wiley Interdiscip Rev Nanomed Nanobiotechnol. 2016;8:223-39.

143. Greene BT, Hughes AD, King MR. Circulating tumor cells: the substrate of personalized medicine? Front Oncol. 2012;2:69.

144. Pestrin M, Bessi S, Galardi F, Truglia M, Biggeri A, Biagioni C, Cappadona S, Biganzoli L, Giannini A, Di Leo A. Correlation of HER2 status between primary tumors and corresponding circulating tumor cells in advanced breast cancer patients. Breast Cancer Res Treat. 2009;118:523-30.

145. Meng S, Tripathy D, Shete S, Ashfaq R, Haley B, Perkins S, Beitsch P, Khan A, Euhus D, Osborne C, Frenkel E, Hoover S, Leitch M, Clifford E, Vitetta E, Morrison L, Herlyn D, Terstappen LWMM, Fleming T, Fehm T, Tucker T, Lane N, Wang J, Uhr J. HER-2 gene amplification can be acquired as breast cancer progresses. Proc Natl Acad Sci USA. 2004:101:9393-8.

146. Fehm T, Becker S, Duerr-Stoerzer S, Sotlar K, Mueller V, Wallwiener D, Lane N, Solomayer E, Uhr J. Determination of HER2 status using both serum HER2 levels and circulating tumor cells in patients with recurrent breast cancer whose primary tumor was HER2 negative or of unknown HER2 status. Breast Cancer Res. 2007;9:R74.

147. Krebs MG, Hou J-M, Ward TH, Blackhall FH, Dive C. Circulating tumour cells: their utility in cancer management and predicting outcomes. Ther Adv Med Oncol. 2010;2:351-65.

148. Stoecklein NH, Fischer JC, Niederacher D, Terstappen LWMM. Challenges for CTC-based liquid biopsies: low CTC frequency and diagnostic leukapheresis as a potential solution. Expert Rev Mol Diagn. 2016;16:147-64

149. Fischer JC, Niederacher D, Topp SA, Honisch E, Schumacher S, Schmitz N, Zacarias Fohrding L, Vay C, Hoffmann I, Kasprowicz NS, Hepp PG, Mohrmann S, Nitz U, Stresemann A, Krahn T, Henze T, Griebsch E, Raba K, Rox JM, Wenzel F, Sproll C, Janni W, Fehm T, Klein CA, Knoefel WT, Stoecklein NH. Diagnostic leukapheresis enables reliable detection of circulating tumor cells of nonmetastatic cancer patients. Proc Natl Acad Sci. 2013;110:16580-5.

150. Eifler RL, Lind J, Falkenhagen D, Weber V, Fischer MB, Zeillinger R. Enrichment of circulating tumor cells from a large blood volume using leukapheresis and elutriation: proof of concept. Cytom Part B Clin Cytom. 2011;80B:100-11.

151. Bersani F, Lee J, Yu M, Morris R, Desai R, Ramaswamy S, Toner M, Habe DA, Parekkadan B. Bioengineered implantable scaffolds as a tool to study stromal-derived factors in metastatic cancer models. Cancer Res. 2014;74:7229-38

152. Azarin SM, Yi J, Gower RM, Aguado BA, Sullivan ME, Goodman AG, Jiang EJ, Rao SS, Ren Y, Tucker SL, Backman V, Jeruss JS, Shea LD. In vivo capture and label-free detection of early metastatic cells. Nat Commun. 2015;6:8094.

153. Mehlen P, Puisieux A. Metastasis: a question of life or death. Nat Rev Cancer. 2006:6:449-58.

154. Egilmez NK, Jong YS, Sabel MS, Jacob JS, Mathiowitz E, Bankert RB. In situ tumor vaccination with interleukin-12-encapsulated biodegradable microspheres: induction of tumor regression and potent antitumor immunity. Cancer Res. 2000:60:3832-7.

155. Hori Y, Stern PJ, Hynes RO, Irvine DJ. Engulfing tumors with synthetic extracellular matrices for cancer immunotherapy. Biomaterials. 2009;30:6757-67.

156. Kwong B, Gai SA, Elkhader J, Wittrup KD, Irvine DJ. Localized immunotherapy via liposome-anchored anti-CD137 + IL-2 prevents lethal toxicity and elicits local and systemic antitumor immunity. Cancer Res. 2013:73:1547-58.

157. Danhier F, Feron O, Préat $\mathrm{V}$. To exploit the tumor microenvironment: passive and active tumor targeting of nanocarriers for anti-cancer drug delivery. J Control Release. 2010;148:135-46.

158. Jewell CM, Bustamante Lopez SC, Irvine DJ. In situ engineering of the lymph node microenvironment via intranodal injection of adjuvantreleasing polymer particles. Proc Natl Acad Sci. 2011;108:15745-50.

159. Wang C, Ye Y, Hochu GM, Sadeghifar H, Gu Z. Enhanced cancer immunotherapy by microneedle patch-assisted delivery of anti-PD1 antibody. Nano Lett. 2016;16:2334-40. 
160. Uto T, Akagi T, Akashi M, Baba M. Induction of potent adaptive immunity by the novel polyion complex nanoparticles. Clin Vaccine Immunol. 2015;22:578-85.

161. Holzapfel BM, Wagner F, Thibaudeau L, Levesque J-P, Hutmacher DW. Concise review: humanized models of tumor immunology in the 21st century: convergence of cancer research and tissue engineering. Stem Cells. 2015;33:1696-704.

162. Soofiyani SR, Hallaj-Nezhadi S, Lotfipour F, Hosseini AM, Baradaran B. Gene therapy based on interleukin-12 loaded chitosan nanoparticles in a mouse model of fibrosarcoma. Iran J. Basic Med Sci. 2016;19:1238-44.

163. Sabel MS, Su G, Griffith KA, Chang AE. Intratumoral delivery of encapsulated IL-12, IL-18 and TNF-a in a model of metastatic breast cancer. Breast Cancer Res Treat. 2010;122:325-36.

164. Tincer G, Yerlikaya S, Yagci FC, Kahraman T, Atanur OM, Erbatur O, Gursel I. Immunostimulatory activity of polysaccharide-poly(l:C) nanoparticles. Biomaterials. 2011;32:4275-82

165. Zhang Y, Luo W, Wang Y, Chen J, Liu Y, Zhang Y. Enhanced antitumor immunity of nanoliposome-encapsulated heat shock protein 70 peptide complex derived from dendritic tumor fusion cells. Oncol Rep. 2015:33:2695-702.
166. Warashina S, Nakamura T, Sato Y, Fujiwara Y, Hyodo M, Hatakeyama H, Harashima H. A lipid nanoparticle for the efficient delivery of siRNA to dendritic cells. J Control Release. 2016;225:183-91.

167. Chen W, Yan W, Huang L. A simple but effective cancer vaccine consisting of an antigen and a cationic lipid. Cancer Immunol Immunother. 2008:57:517-30

168. Uto T, Akagi T, Yoshinaga K, Toyama M, Akashi M, Baba M. The induction of innate and adaptive immunity by biodegradable poly( $(\gamma$-glutamic acid) nanoparticles via a TLR4 and MyD88 signaling pathway. Biomaterials. 2011;32:5206-12.

169. Thomann-Harwood L, Kaeuper P, Rossi N, Milona P, Herrmann B, McCullough KC. Nanogel vaccines targeting dendritic cells: contributions of the surface decoration and vaccine cargo on cell targeting and activation. J Control Release. 2013;166:95-105.

170. Purwada A, Tian YF, Huang W, Rohrbach KM, Deol S, August A, Singh A. Self-assembly protein nanogels for safer cancer immunotherapy. Adv Healthc Mater. 2016;5:1413-9.

171. Chen DS, Mellman I. Oncology meets immunology: the cancer-immunity cycle. Immunity. 2013;39:1-10. 